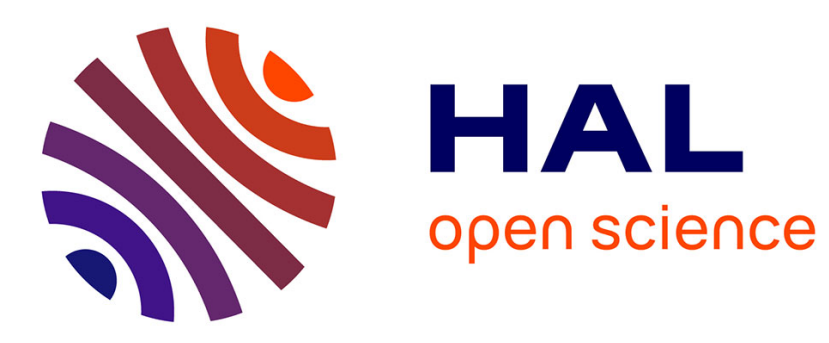

\title{
International risk spillover in the sovereign credit markets: An empirical analysis
}

\author{
Saker Sabkha, Christian de Peretti, Dorra Mezzez Hmaied
}

\section{To cite this version:}

Saker Sabkha, Christian de Peretti, Dorra Mezzez Hmaied. International risk spillover in the sovereign credit markets: An empirical analysis. Managerial Finance, 2019, 45 (8), pp.1020-1040. 10.1108/MF11-2017-0490 . hal-01652526

\section{HAL Id: hal-01652526 https://hal.science/hal-01652526}

Submitted on 30 Nov 2017

HAL is a multi-disciplinary open access archive for the deposit and dissemination of scientific research documents, whether they are published or not. The documents may come from teaching and research institutions in France or abroad, or from public or private research centers.
L'archive ouverte pluridisciplinaire HAL, est destinée au dépôt et à la diffusion de documents scientifiques de niveau recherche, publiés ou non, émanant des établissements d'enseignement et de recherche français ou étrangers, des laboratoires publics ou privés. 


\title{
International risk spillover in the sovereign credit markets: An empirical analysis
}

\author{
Saker Sabkha ${ }^{1,2}$, Christian de Peretti ${ }^{1}$ and Dorra Hmaied ${ }^{2}$ \\ ${ }^{1}$ Univ Lyon, University Claude Bernard Lyon 1, \\ Institute of Financial and Insurance Sciences, \\ LSAF-EA2429, F-69007, Lyon, France \\ ${ }^{2}$ Univ of Carthage, Institute of High Commercial Studies, \\ LEFA, Tunis, Tunisia
}

\begin{abstract}
The occurrence of more and more financial crises characterized not only by their persistence but especially by their severity and magnitude encourages further investigation on portfolio diversification and financial assets' comovements. This paper studies the volatility spillover among 33 worldwide Sovereign Credit Default Swap markets and their underlying bond markets. Conversely to the studies of the literature, heteroscedasticity, asymmetric leverage effect and long-memory features of sovereign credit spreads are simultaneously taken into account through a bivariate FIEGARCH model and a Bayesian cointegrated VAR model. Similarly to the literature, our findings confirm strong evidences of credit risk spillover between credit markets accentuated during crisis periods. However, our country by country analysis allows us to show that countries exhibit different sensitivity levels and reactions' divergences to financial shocks. Further, we show that the bidirectional interrelationship evolves over time and across countries emphasizing the necessity of time-varying national regulatory policies and trading positions.
\end{abstract}

\section{JEL Classification}

G01, G15, F30

\section{Keywords}

Sovereign CDS and bond markets, Dynamic Conditional Correlation, Bayesian cointegrated VAR, Contagion, Risk spillover 


\section{Introduction}

Aiming to control the financial stability, to anticipate financial turmoil and to appropriately balance risk against profitability in investment mix, portfolio managers and policy makers assign a high priority to understand the risk spillover over time and among various credit markets. This issue is, actually, to be addressed to determine and develop both the optimal level of portfolio diversification with the associated risks and the indispensable regulatory policies for macroeconomic-level financial supervision. With the considerable arising questions about the financial markets' comovement dynamics, a particular interest is given to interrelationships between the credit derivatives and the bond markets in both academic and non-academic backgrounds. Despite the perpetually increasing number of studies on the proper credit risk assessment, the lead-lag relationship of the credit spreads' second order remains of importance and needs deeper investigation particularly after the world credit markets integration and the occurrence of financial crises. In fact, the necessity of comprehending and assessing the interaction between credit spreads volatility and the spillover effect between credit derivatives and their underlying markets remains a crucial issue in financial research, whether to avail of arbitrage opportunities, to realize some hedging operations or to speculate on the predictability of the borrowing cost. Yet, understanding in which way and how intense shocks are spreading among credit derivative and debt markets is very important, so economists, regulators and policy makers can anticipate credit markets' reactions to turmoil periods and reduce, thus, the extent of financial instability.

Several works consider the interrelationship between derivative assets and their underlying markets and focus, notably, on the co-movement dynamics of the CDS and the bond market. This strand of research can be divided into three groups following the purpose: First, research focus on the identification of the price discovery process origin. Second, another part of the literature works on the explanation of the price difference between CDS spreads and Bond spreads (CDS-Bond basis) by means of several financial and economic variables. Third, other empirical works consider this dynamic relation in the context of a shock transmission and contagion mechanism. Our paper fits in the third category and examines the volatility spillover between the sovereign CDS market and the underlying bond market of 33 countries with different economic status and belonging to five different international geographical regions during a long period spanning from January 2006 until April 2014 covering the Global Financial Crisis as well as the Sovereign Debt Crisis.

The main works, studying shocks transmission between CDS and bond generally focus on the spreads' first moment and suppose a non-informational volatility interaction ${ }^{[1]}$. These studies are also based on empirical approaches and methodologies that present some econometric issues: For example, the use of VAR model in its different forms is not necessary heteroskedasticity robust which distorts the results of cointegration and causality. Further, the use of joint volatility processes, through multivariate DCC or BEKK models, is not sufficient if the credit spreads statistical properties are not all taken into account. Moreover, most of the studies samples are composed by regional countries and gives thus only restricted evidences that is not straightforwardly suitable for other regions exhibiting different

\footnotetext{
${ }^{[1]}$ For volatility spillover analysis, Tamakoshi and Hamori (2016) examine corporate indexes for banking, life insurance and other UK financial sectors over a period spanning from 2008 until 2013.
} 
characteristics.

This article contributes to the existing literature in several ways while studying the dynamic volatility transmission between the underlying bond market and their sovereign Credit Default Swaps. First, unlike most of the previous studies, the aforementioned methodological shortcomings are filled by providing an improvement in the usual econometric framework: our results rely on both a reduced-form of the VAR model and an extensive-form of the multivariate GARCH model. Second, in order to assess the interconnectedness and the volatility spillover effects among the CDS and the bond markets, a class of model based on the AR(1)FIEGARCH(1,d,1)-DCC is carried out, whose relevance is justified by the identification of the credit markets' particular properties. And so, the leverage effect, the asymmetric power and the long memory behavior of sovereign CDS and bond spreads are taken into consideration in the volatility spillover estimation. As proved by the results of our model, admitting these specifications in a multivariate model's computation adds more robustness to the empirical results and provides more relevant decision-making process. Third, our econometric technique controls and exploits the heteroscedasticity in the Bayesian Vector Error Correction model which allows the Granger-Causality test in mean to capture both small and extreme risk propagation. Fourth, we use a worldwide countries sample representing the international context so we can study the risk spillover among countries with different economic characteristics and financial features and give, thus; some general evidences. Fifth, unlike previous study, our data covers the Global Financial Crisis as well as the Sovereign Crisis during which trading CDS contracts no longer only concerns hedging operations but also arbitrage and speculation. The studied period allows us, then, to examine the impact of crises on risk spillover dynamics. Finally, our study is not limited to country-by-country analysis but also investigates the reactions of synthetic financial portfolios constructed using economic growth, regional and credit rating criteria.

Even though several researchers studied the co-movement relationship between the CDS market and the underlying bond market, our paper is the first to include further significant credit spreads properties in the volatility transmission estimation model which gives more robustness to the results. In fact, the investigation through the FIEGARCH-DCC model and the BVECM model detects greater shock transmission across worldwide credit derivative and their underlying markets. The study of such phenomenon during a long period covering the recent two financial crises reveals that the risk transmission is even more important during turmoil phases. Yet the analysis of countries with dissimilar characteristics shows different sensitivity degree and reaction direction that fluctuate over time and across markets. Finally, besides the country-by-country credit spreads' analysis, our paper examines the volatility spillover between synthetic financial portfolios constructed following several criteria: the economic growth, the region and the credit rating.

The rest of the paper is organized as follows: Section 2 depicts the literature reviews on the comovement between the CDS and their underlying markets. Section 3 displays the data used and the econometric framework. Empirical results and discussion are presented in section 4, while section 5 is dedicated to the concluding remarks and implications. 


\section{Literature review on CDS and underlying bonds}

The interconnectedness between capital markets have been abundantly assessed in the financial literature. A specific strand of these researchers, focusing on information and/or shock transfer between the CDS and the underlying bond markets, is of particular interest in this paper. Even though the approach is the same, these various studies can be divided into three groups following the purpose.

\subsection{The price discovery process}

Researchers, focusing on the price discovery process, aim to determine the origin of the credit price formation. The earliest study conducted by Zhu (2006) shows that CDS takes the lead in the price adjustment process. Focusing on the Japanese mega-banks' credit spreads, Baba et al. (2007) empirically find, as well, that corporate CDS market plays the primary and the dominant role in the price discovery process of credit risk to the detriment of the underlying bond market. In contrast, using daily data of 8 emerging countries, Bowe et al. (2009) show that - even though the average price difference is positive reflecting the preeminence of the CDS spreads over the Bond spreads - the CDS market does not take the lead of the price discovery process. Coudert and Gex (2013) concentrate the analysis on the GM and Ford crisis periods and confirm the previous findings. These authors study the interaction between corporate credit markets during the General Motors and Ford crisis and reveal that these two markets trace each other and that corporate CDS market influences the bond one with an intensification of this interaction pattern during turmoil phases. When it comes to sovereign markets, the interrelationship seems to reverse and the low-yield bond market gets back on top of the price discovery process. Based on results of country-level analysis and using a time varying vector autoregression on 5 -year and 10-year maturity contracts, Calice et al. (2013) show that these two markets comove closely. However, the main finding of this paper is that the liquidity of the CDS market has an important impact on the bond spread. Furthermore, authors empirically demonstrate that this information transmission and interaction mechanism differ from one country to another and depends on maturities. Yet, this trend is more important during turmoil period where the CDS market clearly overtakes the bond market in most cases. This study is only limited to European countries. More recently, Fontana and Scheicher (2016) present different findings where the price discovery process depends not only on the countries' specifications but also on arbitrage and liquidity effects. Focusing on sovereign CDS of 10 euro area countries over a period spanning from 2006 to 2010, the authors show that, as expected, the price adjustment is initially observed in the CDS market but after September 2008, the mechanism changes the direction and takes place in the bond market.

\subsection{The determinants of the price divergence}

Another strand of the literature tries to explain the price divergence between CDS spreads and Bond spreads (CDS-Bond basis) by using several domestic and international variables as proxies for assets' properties. Cossin et al. (2005) show that, unlike the theoretical parity, corporate CDS premiums and bond spreads of the 180 most liquid European companies are 
not closely related in the short run, and they show that this pricing difference is mainly explained by the liquidity premium and the contract specifications (the cheapest to deliver option). Blanco et al. (2005) find an equilibrium relationship between theses credit derivatives and the corresponding bond spreads in the long-run. These authors argue that the parity deviation in the short-run arises from the CDS contracts' imperfections and from, eventually, some measurement errors of the bond spread due to risk-free rate inappropriateness. Studying 33 private reference entities mainly from the USA, the UK, France and Germany, belonging to more than 4 sectors, the authors subsequently suggest that the credit risk part in the CDS spreads is upper-estimated while it is undervalued in the bond spreads especially in Europe. Longstaff et al. (2005) investigate the same issue in an international context represented by data on European and American firms. They explain the divergence in corporate credit risk spreads by a non-default risk component related to bond-specific illiquidity and macroeconomic fundamentals of the credit market. Using a panel VECM, Zhu (2006) also finds that the theoretical parity between CDS and bond spreads is only valid in the long-run. However, this cointegration relationship does not exist in the shortrun because of the differences in reactions to some credit conditions. The author affirms that the liquidity premium greatly impacts the credit risk pricing while the cash market plays a neglected role, especially in the US market from 1999 to 2002. The same conclusions are drawn for the sovereign credit markets by Ammer and Cai (2011) using a sample of 9 emerging countries. Bai and Collin-Dufresne examine the cross-sectional determinants of the price difference between the two contracts and explain that the more the counterparty risk component, the risk premium and the collateral margin of the bond are important, the more the difference measure is large. More lately, Gilchrist and Mojon (2016) investigate credit risk measures of financial and non-financial Euro companies and find that the Global Financial crisis has negatively impacted the borrowing cost reflected in the bond spread of these firms, while the US doc-com bubble of 2000s has only impacted the non-financial corporations. Authors find, as well, that the financial crisis has widened the cross-countries price difference between the CDS and the bond spreads due to national and not euro area credit conditions. All these cited studies point out the shortcoming of the arbitrage theory that supposes a non-arbitrage necessary condition between the two markets.

\subsection{The dynamic relation of shock transmission}

Other empirical works consider this dynamic relation in the context of a shock transmission and contagion mechanism. Different empirical approaches - controlling for endogeneity or serial correlation - are used to assess the risk spillover across these two markets. Baba et al. (2007) find empirically that shocks spill over from the CDS to the bond market but no feedback transmission is found. Norden and Weber (2009) give interesting findings about the comovement relationship between CDS, bonds and stock markets in the private sector over a very short period of 2 years (2000-2002). Using a VAR model, these authors show that financial shocks first affect the stock market before spreading to the CDS and the bond markets. Besides, further evidences are displayed and reveal that, in most countries under focus, the CDS market is more vulnerable to shocks than the bond one. The CDS market contributes more than the bond market in the credit risk transmission channel. Forte and Pena (2009) study the credit risk discovery process of 17 non-financial companies from North 
America and Europe and confirm that shock transmission takes place from the CDS to the corresponding bond market. Delatte et al. (2012) study the mutual influence between the CDS and the underlying bond market during a relatively short period, as well, spanning from 2009 to 2010. They figure out that this interconnection is more intense during distress period and that the non-linear risk transfer from the sovereign CDS market to the bond market depends on the market conditions. The direction of the credit markets dynamics gets reverse when it comes to core-European countries.

\subsection{The risk-free reference rate}

Because of a homogeneity issue, the majority of the above-cited studies transform the bond yields into bond spreads regarding the risk-free rate. A large body of the literature addresses the appropriate choice issue of the risk-neutral reference rate. Longstaff et al. (2005) and Ismailescu and Phillips (2015) promote the use of the US treasury yield when it comes to studying an extensive dataset of European and American corporate bonds while other authors are more flexible and use yields of bonds issued by the lowest risky government in the area. For instance, to construct bond spreads of the Euro area, authors use the German federal government securities as a risk-free rate while they use the US treasury yield for American reference entities ${ }^{[2]}$ (Blanco et al., 2005; Delatte et al., 2012; Coudert and Gex, 2013; Gyntelberg et al., 2013; Costantini et al., 2014; Eichler, 2014; Fontana and Scheicher, 2016; Gilchrist and Mojon, 2016).

In the same context, Cossin et al. (2005) use the 5-year JPMorgan EMU government investment-grade bond index as a proxy for the risk-free rate to calculate the European corporate bond spread. Working on an assessment of the deterministic dynamics of credit spreads in emerging countries, Delatte et al. (2012) use relatively the same reference rate with different $\mathrm{EMBI}^{[3]}$ JPMorgan index for each geographical region. Finally, Zhu (2006) prefers the use of the zero-coupon treasury.

Another strand of the literature argues that governments are no more considered as riskless entities and their issued government yields cannot be a good proxy for the risk-free rate due to tax charges, legal factors and other macroeconomics factors (Bai and CollinDufresne). That's why, the US swap rate is used as the risk-neutral rate instead of the government bond yield (Blanco et al., 2005; Forte and Pena, 2009; Ammer and Cai, 2011; Bai and Collin-Dufresne; Fontana and Scheicher, 2016). The swap rate seems to be an accurate choice since derivatives traders commonly use it as a reference in their pricing models. Yet, Hull et al. (2004) prove empirically that swap rate is more representative of the risk-free rate than US treasuries rates. Nevertheless, the use of swap rates does not seem relevant for European countries. Indeed, being low risky, the bonds issued by these countries have very low yields, with negative spreads in most cases. The literature based on emerging countries, where credit risk is quite high, proposes an alternative approach.

Since there is no certainty about the most appropriate benchmark, Norden and Weber (2009) use several free interest rate term structures: government bond yield curves of

\footnotetext{
${ }^{[2]}$ Calice et al. (2013) use the 5 year German bund as a risk-free rate for EU and Turkish banks and the UK gilt rate for US banks.

${ }^{[3]}$ Emerging Market bond index.
} 
Deutsche Bundesbank, the Federal Reserve Board and the bank of England, the swap rate curves denominated in USD, EUR and GBP and they include a synthetic Euro yield curve.

\subsection{Econometric approaches and literature limits}

Focusing on the third strand of the literature dealing with the contagion phenomenon in financial markets in general and the risk spillover between CDS and Bond markets particularly, econometric approaches can be classified into two frameworks: On the one hand, some authors employ a Vector autoregressions framework analysis and its extended and reduced forms (structural VAR, Vector Error Correction, Bayesian VAR, VARX...) (Blanco et al., 2005; Zhu, 2006; Baba et al., 2007; Forte and Pena, 2009; Longstaff, 2010; Ammer and Cai, 2011; Delatte et al., 2012; Coudert and Gex, 2013; Lee et al., 2015; Srivastava et al., 2016; Fontana and Scheicher, 2016; Gilchrist and Mojon, 2016; Yu, 2017). On the other hand, other authors propose a multivariate GARCH framework (Baek and Jun, 2011; Calice and Ioannidis, 2012; Audige, 2013; Youssef and Belkacem, 2015; Buchholz and Tonzer, 2016; Tamakoshi and Hamori, 2016). We note that the mentioned studies and many others are based on research methodologies presenting some econometric issues. First, the use of different VAR models to study the dynamics of a shock transfer in financial cross-markets is questionable and subject to several criticisms because of insufficiency in theoretical underpinnings (Lee et al., 2015). Yet, these models have no direct heteroskedasticity-robustness which distorts the results of cointegration and causality. Second, most of the GARCH-type multivariate models used to detect shock transmission does not recognize all the credit spreads specifications which leads to less relevant and significant empirical results. Third, results of the multivariate GARCH studies are based solely on the fact that the transmission of financial shocks from one market to another is identified by a significant increase in assets' dynamic correlations. However, we believe that increasing correlations is justified, in some cases, not by a change in price transmission mechanisms within a country's credit markets, but rather by economic and geographical dependence or by a simple increase in prices' volatility on these financial markets. While the volatility of a financial market increases considerably, its correlation with other financial markets also increases automatically. This is evident even if the underlying relationship between these markets remains constant (Forbes and Chinn, 2004). Thus, this methodological choice seems in this case not totally relevant, at least if it is not associated with any other methodologies or econometric techniques.

Despite the econometric issues, literature on CDS and bond markets presents some further limits. In fact, studies of international context using worldwide samples are scarce. The majority of the studied samples are, indeed, composed by regional countries and since we believe that each country presents different economic and financial characteristics, these regional findings cannot be interpreted as global evidences. Moreover, most of these studies generally focus on the spreads' first moment and suppose a non-informational volatility interaction. We believe that risk spillover is rather detected using conditional volatility rather than spread or log returns. 


\section{Data and Methodology}

\subsection{Data description: CDS and bond spreads}

This paper focuses on the analysis of the interrelationship between the sovereign CDS market and the underlying government bond market in order to detect volatility spillover during the period going from January 2006 until April 2014 covering the Global Financial Crisis and the European Debt Crisis. The sample used is composed by 33 worldwide countries belonging to four different economic status: low economic growth countries (Portugal, Ireland, Italy, Greece and Spain), developed countries (Austria, Belgium, Denmark, Finland, France, Germany, Japan, Latvia, Lithuania, Netherlands, Norway Slovakia, Slovenia, Sweden, UK, and), newly industrialized countries (Brazil, China and Turkey) and emerging countries (Bulgaria, Croatia, Czech, Hungary, Poland, Romania, Russia, Ukraine and Venezuela). The economic classification of these countries is made according to the NU, the CIA World Factbook, the IMF and the World Bank criteria, so as to have homogeneous sample in each category.

The 5-year CDS spreads and the corresponding bond yields are obtained from Bloomberg@and Thomson Reuters $\mathbb{R}$. For sake of homogeneity, 5-year bond yields are transformed into spreads regarding the risk-free interest rate. In this paper, the bond spreads are constructed by relying on the work of Norden and Weber (2009). We choose the 5-year German federal government bond as a reference rate for European countries, and the United States sovereign bonds for American and Asian countries. In order to not reduce our sample size, the Euro-area generic bond is used as a benchmark yield for Germany, and the US Treasury Zero-Coupon Yield Curve for the United States.

\subsection{Econometric Methodology}

The econometric framework adopted in this paper includes two dependent approaches. First, a Dynamic Conditional Correlation model is estimated within the CDS and bond markets of each country following the AR(1)-FIEGARCH(1,1)-DCC model. Next, a Bayesian specification of the cointegrated VAR model is applied to transformed-time series in order to analyze credit risk transmission across markets.

\section{The AR(1)-DCC-FIEGARCH(1,1) framework}

The adopted methodology, in this first step, is inspired by the work of Sabkha et al. (2017) who used this model to identify contagion effect among sovereign CDS markets. The FIEGARCH model of Bollerslev and Mikkelsen (1996) is employed in its multivariate dimension. The accuracy of this model relies on the findings of the preliminary tests that clearly defines the particular features of the sovereign credit markets: a volatility clustering, an asymmetric response of volatility to positive and negative news, a leverage effect and a long-range volatility dependence. Furthermore, the use of this class of model is empirically recommended since it allows for conditional variance flexibility and takes into account previous cross markets' specifications (Conrad et al., 2011; Fantazzini, 2011).

Bivariate dynamic conditional correlation coefficients are estimated following the DCC specifications as proposed by Engle (2002). For each country, time series are assumed to 
follow an $\mathrm{AR}(1)$ process with a t-student marginal distribution.

$$
\left\{\begin{array}{l}
x_{1, t}=a_{1,0}+a_{1,1} x_{1, t-1}+u_{1, t} \\
x_{2, t}=a_{2,0}+a_{2,1} x_{2, t-1}+u_{2, t}
\end{array}\right.
$$

where $x_{1, t}$ and $x_{2, t}$ are respectively the CDS first-differences and the bond first-differences at time $t$. For $i=1,2, a_{i, 0}$, are constant $\in[0, \infty)$ and $\left|a_{i, 1}\right|<1$. $u_{i, t}=\sigma_{i, t} \varepsilon_{i, t}$ where $\varepsilon_{i, t}$ constitute weak white noises such as $E_{t}\left(\varepsilon_{i, t-1}^{2}\right)=1$. $\sigma_{i, t}^{2}$ is positive representing the conditional variance of $x_{i, t}$ such as $\sigma_{i, t}^{2}=\operatorname{Var}\left(x_{i, t} \mid \mathcal{F}_{t-1}\right)$ with $\mathcal{F}_{t}$ is the market information set at a given moment $t$.

In its general form, the DCC model is defined as a time varying variance-covariance structure:

$$
\Omega_{t}=D_{t} H_{t} D_{t},
$$

Where $D_{t}$ is a diagonal matrix of the conditional standard deviation obtained from the univariate models and $H_{t}$ is the $2 \times 2$ time-varying correlation matrix of the standardized error terms $\varepsilon_{t}\left(\right.$ of $\left.x_{t}\right)$ such as:

$$
H_{t}=Q_{t}^{-1} Q_{t} Q_{t}^{-1},
$$

where $Q_{t}$ is symmetric covariance matrix that can be written as follows:

$$
Q_{t}=\bar{Q}(1-\alpha-\beta)+\alpha\left(\varepsilon_{t-1} \varepsilon_{t-1}^{\prime}\right)+\beta Q_{t-1},
$$

With $\bar{Q}$ is a symmetric time invariant matrix of the unconditional correlation coefficients $\left(\overline{\rho_{12}}\right)$ between $\varepsilon_{1, t}$ and $\varepsilon_{2, t} . \quad \alpha$ and $\beta$ parameters are positive and respect the stationarity constraint of $\alpha+\beta<1$. The bivariate dynamic conditional correlation coefficient of Engle (2002) is, thus, defined as:

$$
\rho_{12, t}=\frac{\overline{q_{12}}(1-\alpha-\beta)+\alpha\left(\varepsilon_{1, t-1} \varepsilon_{2, t-1}\right)+\beta q_{12, t-1}}{\sqrt{\left(\overline{q_{11}}(1-\alpha-\beta)+\alpha \varepsilon_{11, t-1}^{2}+\beta q_{11, t-1}\right)\left(\overline{q_{22}}(1-\alpha-\beta)+\alpha \varepsilon_{22, t-1}^{2}+\beta q_{22, t-1}\right)} .}
$$

A prior step to the DCC estimation is to run a univariate FIEGARCH $(1, \mathrm{~d}, 1)$ model for each of the time series in order to obtain the conditional standard deviations, $\sigma_{1, t}$ and $\sigma_{2, t}$. According to Bollerslev and Mikkelsen (1996), a FIEGARCH (p,d,q) model is written as follows:

$$
\ln \left(\sigma_{t}^{2}\right)=\omega_{0}+\phi(L)^{-1}(1-L)^{-d}[1+\psi(L)] g\left(\varepsilon_{t-1}\right) .
$$

With $\phi(L)$ and $\psi(L)$ are lag polynomials, $(1-L)^{-d}$ is the financial fractional differencing operator and $g\left(e_{t}\right)$ is a quantization function of information flows such as $g\left(e_{t}\right)=\theta e_{t}+\gamma[l$ $\left.e_{t} \mid-E\left(\left|e_{t}\right|\right)\right]$ where $\gamma$ is the leverage coefficient. When $\gamma>0$, it means that the impact of bad news (negative shocks) on volatility is more important than the impact of good news (negative shocks with the same absolute magnitude), leading to an increase of the conditional variance in a more proportional way and vise versa. The FIEGARCH $(1, \mathrm{~d}, 1)$ is automatically well-defined and does not need any non-negativity restrictions.

Since contagion is only detected when there is a statistically significant increase in the correlation, Kalbaska and Gatkowski (2012), Dimitriou et al. (2013) and Kenourgios and Dimitriou (2015) propose to regress conditional correlations $\left(\rho_{t}\right)$ on their lagged values $\left(\rho_{t-1}\right)$ 
and dummy variables representing different crisis periods $\left(D_{k}\right)$. We follow this approach and we consider the following equation:

$$
\rho_{t}=\mu_{0}+a_{1} \rho_{t-1}+b_{k} D_{k}+\eta_{t}
$$

where $\alpha_{0}$ is a constant $\in[0, \infty), \rho_{t}$ is the time-varying conditional correlation between the CDS and the bond markets. $\mathrm{k}$ corresponds to the crisis index, it is equal to 1 when it's about the first financial crisis and equal to 2 when it comes to the sovereign crisis. In this paper, we use the same length and crises' timeline as Sabkha et al. (2017) and divide our studied period into four sub-periods:

- From January 2006 to June 2007: a reference period;

- From July 2007 to March 2009: $1^{\text {st }}$ crisis period (financial crisis);

- From November 2009 to March 2012: $2^{\text {nd }}$ crisis period (Sovereign Debt crisis);

- From March 2012 to April 2014: Post-crisis period (tranquil period).

\section{The Bayesian VECM framework}

The analysis of the credit risk spillover goes through studying the lead-lag relationship between financial assets. This dynamic relation is frequently modeled using the vector autoregressive (VAR). This estimation method does not explicitly consider for several financial data properties such as endogeneity, serial correlation or non-normality. To overcome these shortcomings in this paper, a restricted form of the VAR method is applied to transformed time series. The transformation technique allows us to take into account the presence of heteroscedasticity, among other features, in the spreads under investigation.

For each spread, a special treatment is applied to each time series though the following transformation-equation: $y_{t}=\frac{x_{t}-\mu_{t}}{\sigma_{t}^{2}}$. With $y_{t}$ is the new transformed time series, $x_{t}$ is the CDS (or Bond) spread at time t, $\mu_{t}$ and $\sigma_{t}^{2}$ are respectively the conditional mean and the conditional variance of the spread obtained from the estimation of the univariate FIEGARCH model. In this way, heteroscedastic properties, asymmetric leverage effect and long-memory behavior of CDS and bond spreads are considered in the converted-time series.

To overcome information loss due to stationary techniques, the restricted form of VAR, as proposed by Johansen et al. (1991) considering for the non-stationarity and the cointegration of macroeconomic and financial time series is employed in this paper rather than the commonly used unrestricted VAR model of Sims (1980). The main idea of this model is to restrain the long-run paths of explicative variables by forcing the convergence to the cointegration coefficient (error correction term), while the adjustment of the short-run behavior remains unrestricted.

$$
\Delta Y_{t}=\mu+\Gamma \beta^{\prime} Y_{t-1}+\sum_{k=1}^{p} \Pi_{k} \Delta Y_{t-k}+a_{t}
$$

Where $Y_{t}$ is a vector of $N$ explicative variables $(N=2$ in our case) at time t, $\Pi$ is $N \times N$ parameters matrix of the short-run relationship, $\Gamma$ and $\beta^{\prime}$ denote matrices of receptively the error correction terms and the the long-run coefficients $\mu$ is a deterministic component and $a_{t}$ represents the innovations. 
Another restrictive version of the general vector autoregressions is the Bayesian VAR introduced by Litterman (1986). This new class of model avoids the estimation problem of over-parameterization by proposing some restrictions in the prior distribution functions. Initial specifications allow for calibrating the prior residual covariance matrix parameters by controlling the prior mean and the tightness of the variance. The use of the Bayesian form is recommended when the studied period is short and the number of observations is limited (Cuestas, 2017).

Given that our series contain stochastic trends (random walk process)(Table 1) and show highly significant cointegrating relationships (Results can be given upon request), and in order to avoid over-fitting issues, the use a Bayesian Vector Error correction model combining specifications of both previous restrictive models, is appropriate. This approach concedes more reliability and efficiency to the parameters estimates with particular respect to the long-run equilibrium. In consideration of several non-identification issues, prior elicitation in multivariate models is an important step. Our analysis, being based upon this Bayesian econometrics, is relevant as it has been already used in the macroeconomic context knowing that financial variables exhibit same statistical properties as macro-aggregates. In fact, macroeconomic application shows that the Bayesian VAR with an error correction parametrization outperforms both standard and cointegrated VAR (Félix et al., 2003; Koop et al., 2005).

We follow the work of Amisano and Serati (1999) and give some informative prior to the $\Gamma$ and $\beta^{\prime}$ (factor loadings coefficients) matrices. Restrictions are imposed to the estimated adjustments terms using the results of the Johansen system cointegration test ${ }^{[4]}$. The loadings factor matrices allow us to give more importance to the cointegrating relationships with no restriction in the short-run dynamics - and to define the speed of their convergence.

The interrelationship between the CDS and the bond markets can be expressed, through the Bayesian vector autoregressions with error correction, as functions of the cointegrating terms and their mutual lagged values:

$$
\begin{aligned}
& \Delta y_{1, t}=\lambda_{1} e_{t-1}+\sum_{k=1}^{p} \gamma_{1} \Delta y_{1, t-k}+\sum_{k=1}^{p} \delta_{1} \Delta y_{2, t-k}+a_{1, t}, \\
& \Delta y_{2, t}=\lambda_{2} e_{t-1}+\sum_{k=1}^{p} \gamma_{2} \Delta y_{2, t-k}+\sum_{k=1}^{p} \delta_{2} \Delta y_{1, t-k}+a_{2, t} .
\end{aligned}
$$

with $y_{1}$ and $y_{1}$ represent respectively the transformed time series of the sovereign CDS and the government bonds, $\lambda$ is the adjustment coefficient of each market and $e_{t}$ is a deviation from the long-run equilibrium estimated from the following equation: $p_{t}=c_{0}+c_{1} s_{t}+e_{t}$.

After estimating the BVECM, a Granger causality (GC, hereafter) test is applied in order to detect any contagion phenomenon between the two markets and to check for the risk transfer direction. The main problem with the classical Granger causality test in mean, is that it assumes conditional homoscedasticity, which distorts the results since most financial time series exhibit autocorrelation behavior (Hong, 2001; Srivastava et al., 2016). This problem is not encountered in our paper since we control for the ARCH-type effect by using

\footnotetext{
${ }^{[4]}$ Besides the cointegration rank, the Johansen test estimates unrestricted and normalized cointegrating coefficients and unrestricted error correction coefficients.
} 
transformed data ${ }^{[5]}$. The general GC test formalization, as proposed by Granger (1969), supposes the null hypothesis of independence between past values of $y_{2}$ and the present and future values of $y_{1}$ (no bivariate causality). If $y_{2}$ doesn't Granger cause $y_{1}$ in the strict sense, then:

$$
P\left[y_{1, t} \mid \mathcal{F}_{t-1}\right]=P\left[y_{1, t} \mid\left(\mathcal{F}_{t-1}-y_{2, t-h}^{h}\right)\right],
$$

where $P\left(y_{t} \mid \mathcal{F}_{t-1}\right)$ is the conditional probability distribution of the $y_{t}$ and $\mathcal{F}_{t-1}$ is the information set available at time $t-1 . y_{t}^{h}$ is the h-length lagged vector of the transformed time series such as $y_{t}^{h} \equiv\left(y_{t-h}, y_{t-h+1} \ldots y_{t-1}\right)$. Furthermore, $y_{2}$ doesn't instantaneously Granger cause $y_{1}$ when:

$$
P\left(y_{1, t} \mid \mathcal{F}_{t-1}\right)=P\left[y_{1, t} \mid\left(\mathcal{F}_{t-1}+y_{2, t}\right)\right] .
$$

When the null hypothesis is rejected (see Equation 10 and Equation 11), we can say that $y_{2}$ Granger causes $y_{1}$.

\subsection{Synthetic portfolios' construction}

As mentioned before, our paper is not limited to country-by-country analysis, but it examines as well the volatility spillover between CDS and bond markets of synthetic financial portfolios constructed in concordance with the economic growth, the region and the credit rating. Several studies exist in the literature regarding the optimal non-cash asset allocation weight methods (Equal-weight, volatility weight, value-weight...). We are inspired by the valueweighting technique and suppose that, whether for the CDS or the bond portfolios, each country's weight is defined by dividing its transaction volume (outstanding debt amount) by the total transaction volume of the portfolio, such as:

$$
P=\sum_{i=1}^{N} w_{i} x_{i}
$$

Where $\mathrm{P}$ is the synthetic portfolio, $\mathrm{N}$ is the number of non-cash assets in the portfolio, $x_{i}$ is the CDS (or Bond) spreads and $w_{i}=\frac{v_{i}}{v_{p}}$ with $v_{i}$ is the country's transaction volume on the credit market and $v_{p}$ is the total transaction volume of all the countries composing the portfolio.

The synthetic portfolios are used as proxies to reproduce the credit markets of some areas or some economic categories. The objective of replicating portfolios in this paper is to aggregate and study countries in the same region, with the same economic level and/or with the same credit risk classification.

\section{Empirical results}

\subsection{Descriptive statistics}

Table 1 reports descriptive statistics of the time series for each studied country. CDS and Bond daily spreads of different countries fluctuate from -191.85 bp to 5304.9 (Except for

\footnotetext{
${ }^{[5]}$ Other solutions exist as to take into account the heteroscedasticity. Hong (2001) proposes a specific Granger-causality test in the mean that considers for the serial correlation and infinite unconditional variance, while Srivastava et al. (2016) suggest resolving the problem by conducting the test on the conditional variance.
} 
Greece that reaches 37688 bp). Different countries' average spreads are not at the same level - which is explained by the heterogeneity of our sample - but are almost always positive (for Germany, USA and Japan the average bond spread is negative). Negative credit spreads have several explanations. First, during financial turmoil, market participants choose to invest in government riskless assets rather than in corporate assets, which explains that some countries (Germany among others) issue bonds with negative yields (Dolvin, 2012). Second, Beber et al. (2009) and Bhanot and Guo (2011) interpret the negative spreads as a temporary liquidity problem making interest rate downgrade. This phenomenon can also be explained by a bad choice of the risk-free rate. Almost all our time series exhibit significant excess kurtosis and positive skewness coefficients, which implies a presence of several extreme values and a bigger fat tail than what expected from a Gaussian distribution. These results are in line with the Jarque-Bera test that confirms the non-normality of the data distribution at the $1 \%$ statistical level of significance. As expected, CDS and bond spreads are found to be non-stationary according to the Augmented Dickey-Fuller's test.

To overcome the presence of unit-roots in our time series, first-differences are estimated for each country such as $X_{t}=x_{t}-x_{t-1}$ with $x_{t}$ is the CDS (or the Bond) spread at time $t$. Figure 1 displays the plots of CDS and bond first-differences over time. It is clearly shown that changes are stationary. CDS and bond spreads changes exhibit a relatively similar time-varying evolution dynamics.

Preliminary tests are reported in Table 2. As in the level data analysis, spreads changes exhibit significant skewness and excess kurtosis implying the presence of several extreme values. The non-normality of spreads' changes is confirmed by the Jarque-Bera test at the $1 \%$ significant level. To suit the leptokurtic properties of both series, bivariate innovations are allowed to follow a student, a G.E.D (Generalized Error Distribution) or a skewed student distribution. ARCH-type effects are clearly observed and heteroscedastic features are detected. The Ljung-Box statistics show significant autocorrelations with a high order for all countries for both mean and variance equations. Results of the GPH and the Rescaled-Range tests on squared arithmetic returns ${ }^{[6]}$ show that credit spreads exhibit long-memory behavior. Results of these preliminary analysis justify the relevant use of the FIEGARCH(1,d,1)-DCC model.

\subsection{Empirical Findings}

Results of the AR(1)-FIEGARCH(1,d,1)-DCC application to the CDS and bond spreads changes are reported in Table 3 and Table 4 . The country-by-country analysis show that the average conditional correlation is significant in $76 \%$ of the sample and considerably fluctuates from one country to another which underlines once again the heterogeneity of our studied countries. The Beta coefficient is always significant and close to one (Except for Finland, Sweden, the USA and Ukraine) which implies a great multivariate persistence between the CDS market and the Bond market. Leverage effect is statistically significant emphasizing, as well, the important impact of negative innovations on worldwide credit markets. Moreover, the degree of freedom coefficient is always significant at the $1 \%$ statistic level which confirms the results of the Jarque-Bera test. Results show that there is no misspecification in our

\footnotetext{
${ }^{[6]}$ Squared arithmetic returns are used as proxy for CDS and bond unconditional volatility.
} 
Table 1: Descriptive statistics of daily CDS and Bond spreads from January 2006 to April 2014

\begin{tabular}{|c|c|c|c|c|c|c|c|c|c|c|}
\hline & & Obs. & Min. & Mean & Max. & Std. Dev. & Skweness & Excess Kurtosis & Jarque-Bera & ADF statistics \\
\hline \multicolumn{11}{|l|}{ Panel A: PIIGS } \\
\hline \multirow{2}{*}{ Portugal } & $\mathrm{CDS}$ & 2154 & 4,02 & 311,23 & 1527,00 & 356,15 & $1,21 * * *$ & $0,45^{* * *}$ & $544,65 * * *$ & $-0,99$ \\
\hline & Bond & 2154 & $-11,40$ & 368,93 & 2264,00 & 462,05 & $1,45 * * *$ & $1,15^{* * *}$ & $875,16 * * *$ & $-1,06$ \\
\hline \multirow{2}{*}{ Ireland } & CDS & 2154 & 1,75 & 232,90 & 1191,50 & 249,26 & $1,08^{* * *}$ & 0,00 & $414,84 * * *$ & $-0,99$ \\
\hline & Bond & 2154 & $-26,50$ & 228,07 & 1578,00 & 278,79 & $1,51 * * *$ & $2,10^{* * *}$ & $1211,50^{* * *}$ & $-1,20$ \\
\hline \multirow{2}{*}{ Italy } & CDS & 2154 & 5,58 & 161,93 & 591,54 & 148,52 & $0,95 * * *$ & 0,13 & $327,70 * * *$ & $-0,97$ \\
\hline & Bond & 2154 & $-4,10$ & 148,90 & 676,50 & 146,96 & $1,14^{* * *}$ & $0,52 * * *$ & $493,68^{* * *}$ & $-1,11$ \\
\hline \multirow{2}{*}{ Greece } & CDS & 2009 & 5,20 & 8068,60 & 37081 & 14532,00 & $1,45 * * *$ & $0,18 *$ & $711,20 * * *$ & $-1,51$ \\
\hline & Bond & 2154 & $-121,60$ & 9994,00 & 37688 & 14984,00 & $0,98^{* * *}$ & $-0,95 * * *$ & $428,78^{* * *}$ & 3,09 \\
\hline \multirow{2}{*}{ Spain } & CDS & 2154 & 2,55 & 165,66 & 641,98 & 153,97 & $0,79 * * *$ & $-0,21 * *$ & $226,37 * * *$ & $-0,99$ \\
\hline & Bond & 2154 & $-13,90$ & 153,58 & 740,80 & 157,06 & $0,89 * * *$ & $-0,04$ & $285,30 * * *$ & $-1,10$ \\
\hline \multicolumn{11}{|l|}{ Panel B: Developed countries } \\
\hline \multirow{2}{*}{ Austria } & CDS & 2154 & 1,75 & 61,13 & 268,98 & 58,57 & $1,03 * * *$ & $0,42 * * *$ & $393,32 * * *$ & $-1,28$ \\
\hline & Bond & 2154 & $-16,60$ & 36,04 & 213 & 33,51 & $1,44^{* * *}$ & $2,88^{* * *}$ & $1488,70^{* * *}$ & $-2,01$ \\
\hline Beloium & CDS & 2154 & 2,05 & 83,61 & 406,12 & 85,62 & $1,20 * * *$ & $0,63 * * *$ & $556,10^{* * *}$ & $-1,09$ \\
\hline Belgium & Bond & 2154 & $-6,00$ & 62,18 & 438,90 & 66,30 & $1,74^{* * *}$ & $3,60^{* * *}$ & $2254,10^{* * *}$ & $-1,88$ \\
\hline & CDS & 2154 & 9,00 & 42,71 & 158,23 & 37,26 & $1,39 * * *$ & $0,66 * * *$ & $736,64 * * *$ & $-1,06$ \\
\hline Denmark & Bond & 2154 & $-32,40$ & 23,62 & 121,30 & 28,43 & $0,68 * * *$ & $0,18 *$ & $171,12 * * *$ & $-1,80$ \\
\hline Finland & CDS & 2154 & 2,69 & 28,12 & 90,84 & 22,55 & $0,92^{* * *}$ & 0,14 & $302,63 * * *$ & $-0,98$ \\
\hline Fimiana & Bond & 2154 & $-14,00$ & 18,67 & 93,90 & 18,68 & $1,11^{* * *}$ & $0,96 * * *$ & $0,96 * * *$ & $-2,52$ \\
\hline France & CDS & 2154 & 1,50 & 60,58 & 249,63 & 59,07 & $1,14^{* * *}$ & $0,64^{* * *}$ & $504,73^{* * *}$ & $-0,99$ \\
\hline Hrance & Bond & 2154 & $-5,90$ & 30,32 & 184,80 & 29,55 & $1,72 * * *$ & $3,43^{* * *}$ & $2117,20 * * *$ & $-1,89$ \\
\hline & CDS & 2154 & 1,40 & 32,95 & 119,17 & 28,02 & $0,93 * * *$ & $0,20 *$ & $317,04 * * *$ & $-1,06$ \\
\hline Germany & Bond & 2154 & $-107,70$ & $-45,61$ & 3,90 & 20,79 & $-0,60 * * *$ & $-0,23 * *$ & $135,11^{* * *}$ & $-1,16$ \\
\hline & CDS & 2154 & 2,13 & 52,63 & 157,21 & 38,33 & $0,18^{* * *}$ & $-0,88 * * *$ & $80,66 * * *$ & $-0,84$ \\
\hline Japan & Bond & 2154 & $-191,85$ & $-86,22$ & $-18,05$ & 51,87 & $-0,60 * * *$ & $-0,91 * * *$ & $203,23 * * *$ & $-1,75$ \\
\hline Latvia & CDS & 2154 & 5,50 & 258,32 & 1163,00 & 236,02 & $1,13^{* * *}$ & $1,35^{* * *}$ & $789,36 * * *$ & $-1,10$ \\
\hline Latva & Bond & 2154 & 112,20 & 343,09 & 1418,30 & 269,86 & $2,25 * * *$ & $4,20 * * *$ & $3402,20 * * *$ & $-1,09$ \\
\hline lithuania & CDS & 2154 & 6,00 & 203,03 & 847,50 & 171,73 & $1,09 * * *$ & $1,42 * * *$ & $609,11 * * *$ & $-0,94$ \\
\hline LItnuania & Bond & 2154 & $-8,30$ & 288,82 & 145,10 & 273,38 & $1,46 * * *$ & $1,72 * * *$ & $1033,90^{* * *}$ & $-1,86$ \\
\hline Netherlands & CDS & 2154 & 7,67 & 42,61 & 139,84 & 33,41 & $0,92 * * *$ & 0,07 & $306,13 * * *$ & $-0,95$ \\
\hline Netnerlanas & Bond & 2154 & $-15,50$ & 20,02 & 89,40 & 19,92 & $0,84 * * *$ & $0,21 * *$ & $256,60 * * *$ & $-2,39$ \\
\hline Norway & CDS & 2154 & 11,94 & 37,11 & 62,16 & 18,12 & $0,11 * *$ & $-1,77 * * *$ & $285,76 * * *$ & $-1,49$ \\
\hline INorway & Bond & 2154 & 8,10 & 79,45 & 168,70 & 33,13 & $0,31 * * *$ & $-0,26 * *$ & $40,77 * * *$ & $-0,84$ \\
\hline & CDS & 2154 & 5,33 & 87,73 & 328,25 & 74,34 & $1,16^{* * *}$ & $0,83^{* * *}$ & $544,60 * * *$ & $-0,96$ \\
\hline Slovakıa & Bond & 2154 & $-14,80$ & 116,46 & 389,40 & 69,66 & $1,23 * * *$ & $2,20 * * *$ & $979,36 * * *$ & $-0,96$ \\
\hline Slovenia & CDS & 2154 & 4,25 & 138,52 & 511,07 & 136,61 & $0,86^{* * *}$ & $-0,65 * * *$ & $300,37 * * *$ & $-0,65$ \\
\hline Slovenia & Bond & 2154 & 17,30 & 210,14 & 635,00 & 155,37 & $0,70^{* * *}$ & $-0,67 * * *$ & $218,18^{* * *}$ & $-1,08$ \\
\hline & CDS & 2154 & 1,63 & 29,15 & 156,36 & 26,48 & $1,26 * * *$ & $2,33 * * *$ & $1056,00 * * *$ & $-1,25$ \\
\hline Sweden & Bond & 2154 & $-32,80$ & 34,76 & 120,10 & 36,06 & $0,32 * * *$ & $-0,99 * * *$ & $124,19 * * *$ & $-1,26$ \\
\hline UK & CDS & 2154 & 16,50 & 49,04 & 164,79 & 30,52 & $0,76^{* * *}$ & $0,20 *$ & $211,84 * * *$ & $-0,95$ \\
\hline UK & Bond & 2154 & $-64,40$ & 53,99 & 143,10 & 41,52 & $-0,13 * *$ & $-0,57 * * *$ & $35,13^{* * *}$ & $-1,14$ \\
\hline USA & CDS & 2154 & 15,00 & 32,82 & 95,00 & 14,57 & $24,81^{* * *}$ & $693,69 * * *$ & $4340,90^{* * *}$ & $-0,94$ \\
\hline USA & Bond & 2154 & $-165,24$ & $-32,61$ & 112,70 & 32,71 & $0,13 * *$ & $4,29 * * *$ & $1655,90 * * *$ & $-0,98$ \\
\hline Panel C: Newly Industrialize & & & & & & & & & & \\
\hline Brazil & CDS & 2154 & 61,50 & 145,15 & 586,86 & 65,13 & $2,58^{* * *}$ & $8,06 * * *$ & $8218,20^{* * *}$ & $-1,48$ \\
\hline Brazil & Bond & 2154 & 24,30 & 855,47 & 1529,20 & 328,58 & $-1,48 * * *$ & $1,26^{* * *}$ & $92,62 * * *$ & $-0,74$ \\
\hline China & CDS & 2154 & 10,00 & 75,87 & 276,30 & 48,68 & $1,02 * * *$ & $1,57^{* * *}$ & $592,67 * * *$ & $-1,40$ \\
\hline Chına & Bond & 2154 & $-146,30$ & 95,06 & 394,70 & 149,29 & $0,18^{* * *}$ & $-1,22 * * *$ & $145,84 * * *$ & 0,45 \\
\hline Turkey & CDS & 2154 & 110,95 & 214,85 & 831,31 & 82,51 & $2,25 * * *$ & $7,82 * * *$ & $7299,30 * * *$ & $-1,31$ \\
\hline Turkey & Bond & 2154 & 525,10 & 1024,50 & 2345,20 & 349,16 & $0,80^{* * *}$ & 0,01 & $227,52 * * *$ & $-0,48$ \\
\hline Panel D: Emerging countrie & & & & & & & & & & \\
\hline Bulgaria & CDS & 2154 & 13,22 & 198,11 & 699,39 & 140,48 & $0,76^{* * *}$ & $0,40^{* * *}$ & $222,85 * * *$ & $-1,00$ \\
\hline Bulgarla & Bond & 2154 & 3,10 & 212,22 & 535,60 & 139,19 & $0,43^{* * *}$ & $-0,86 * * *$ & $134,71^{* * *}$ & $-1,10$ \\
\hline Croatia & CDS & 2154 & 24,88 & 247,41 & 636,36 & 153,87 & $0,19 * * *$ & $-0,87^{* * *}$ & $81,84 * * *$ & $-0,55$ \\
\hline Croatla & Bond & 2154 & 91,70 & 351,33 & 641,50 & 114,64 & $0,31^{* * *}$ & $-0,42 * * *$ & $51,59 * * *$ & $-0,12$ \\
\hline Czech & CDS & 2154 & 3,41 & 73,94 & 350 & 55,81 & $1,25 * * *$ & $2,79 * * *$ & $1264,70^{* * *}$ & $-1,19$ \\
\hline czecn & Bond & 2154 & $-78,50$ & 66,61 & 257,90 & 70,15 & 0,06 & $-0,50 * * *$ & $23,45 * * *$ & $-1,49$ \\
\hline Hungary & CDS & 2154 & 17,34 & 255,41 & 738,60 & 171,24 & $0,24^{* * *}$ & $-0,77 * * *$ & $73,97 * * *$ & $-0,91$ \\
\hline nungary & Bond & 2154 & 25,30 & 531,43 & 1167 & 172,90 & $0,79 * * *$ & $0,37^{* * *}$ & $236,35 * * *$ & $-0,66$ \\
\hline Poland & CDS & 2154 & 7,67 & 119,28 & 415 & 84,84 & $0,63^{* * *}$ & 0,20 & $141,88^{* * *}$ & $-1,03$ \\
\hline & Bond & 2154 & 66,90 & 282,47 & 468,20 & 99,71 & $-0,42 * * *$ & $-0,85 * * *$ & $126,10^{* * *}$ & $-0,34$ \\
\hline Romania & CDS & 2154 & 17,00 & 236,50 & 764,75 & 158,49 & $0,68^{* * *}$ & $0,59 * * *$ & $197,19 * * *$ & $-1,01$ \\
\hline Romanıa & Bond & 2154 & 293,80 & 548,99 & 1317,70 & 206,93 & $0,87^{* * *}$ & $0,63 * * *$ & $306,16 * * *$ & $-0,55$ \\
\hline Russia & CDS & 2154 & 36,88 & 191,184 & 1113,40 & 154,53 & $2,54 * * *$ & $7,70^{* * *}$ & $7627,10^{* * *}$ & $-1,83$ \\
\hline Russia & Bond & 2154 & 171,10 & 527,03 & 1567,80 & 253,39 & $0,51^{* * *}$ & $-0,03$ & $92,08 * * *$ & $-0,25$ \\
\hline Ukraine & CDS & 2154 & 126,13 & 767,11 & 5304,90 & 760,94 & $2,67 * * *$ & $8,33 * * *$ & $8783,40 * * *$ & $-1,29$ \\
\hline Ukrame & Bond & 2154 & 723,10 & 1087,20 & 2802,50 & 462,45 & $1,55 * * *$ & $1,28 * * *$ & $1009,30 * * *$ & $-0,56$ \\
\hline Venez & CDS & 2154 & 126,13 & 767,11 & 5304,90 & 760,94 & $2,67^{* * *}$ & $8,33 * * *$ & $8783,40 * * *$ & $-1,29$ \\
\hline venezuela & Bond & 2154 & $-73,50$ & 1048,10 & 1899,40 & 558,29 & $-0,54 * * *$ & $-1,07 * * *$ & $206,90 * * *$ & $-1,85$ \\
\hline
\end{tabular}



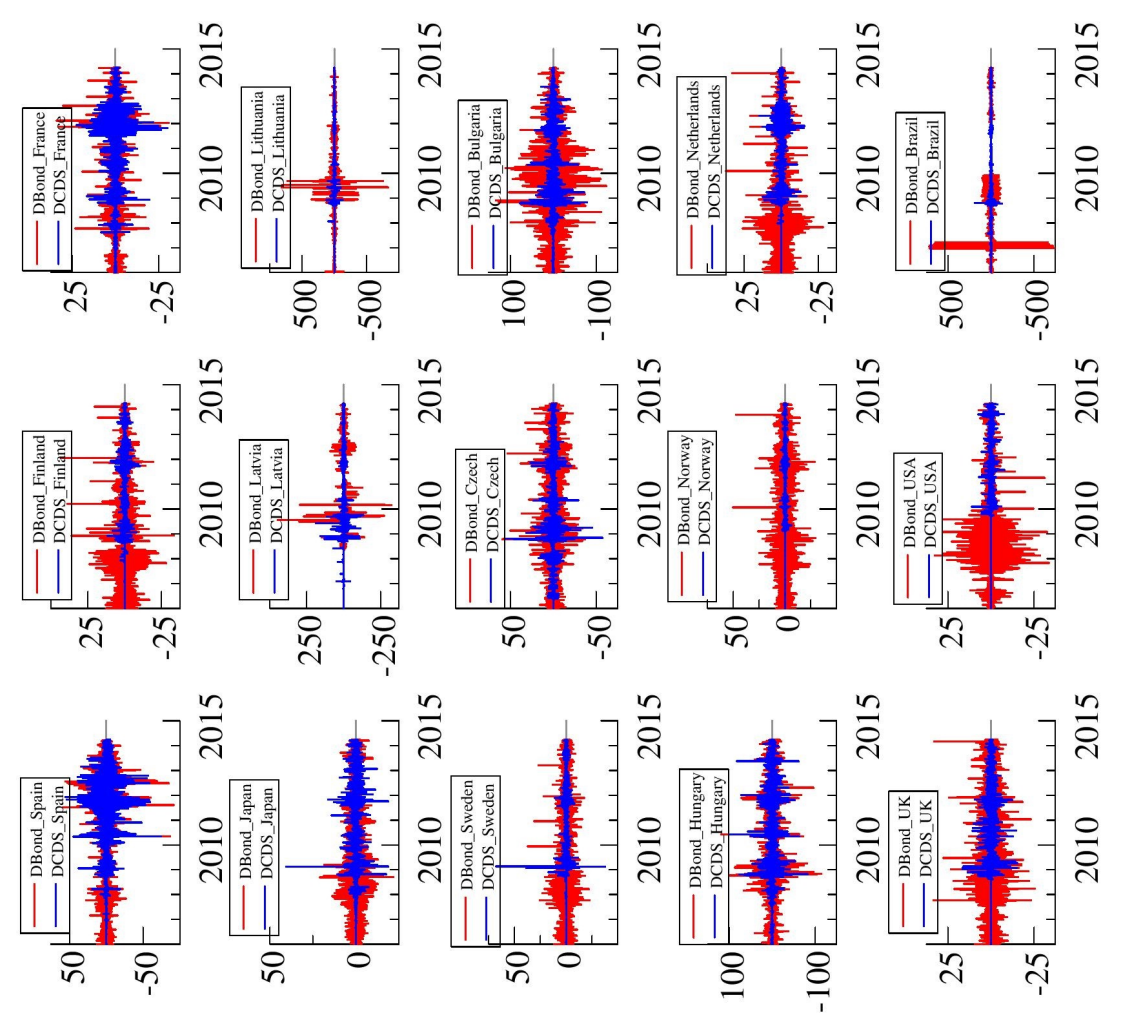

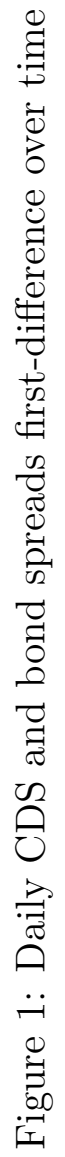
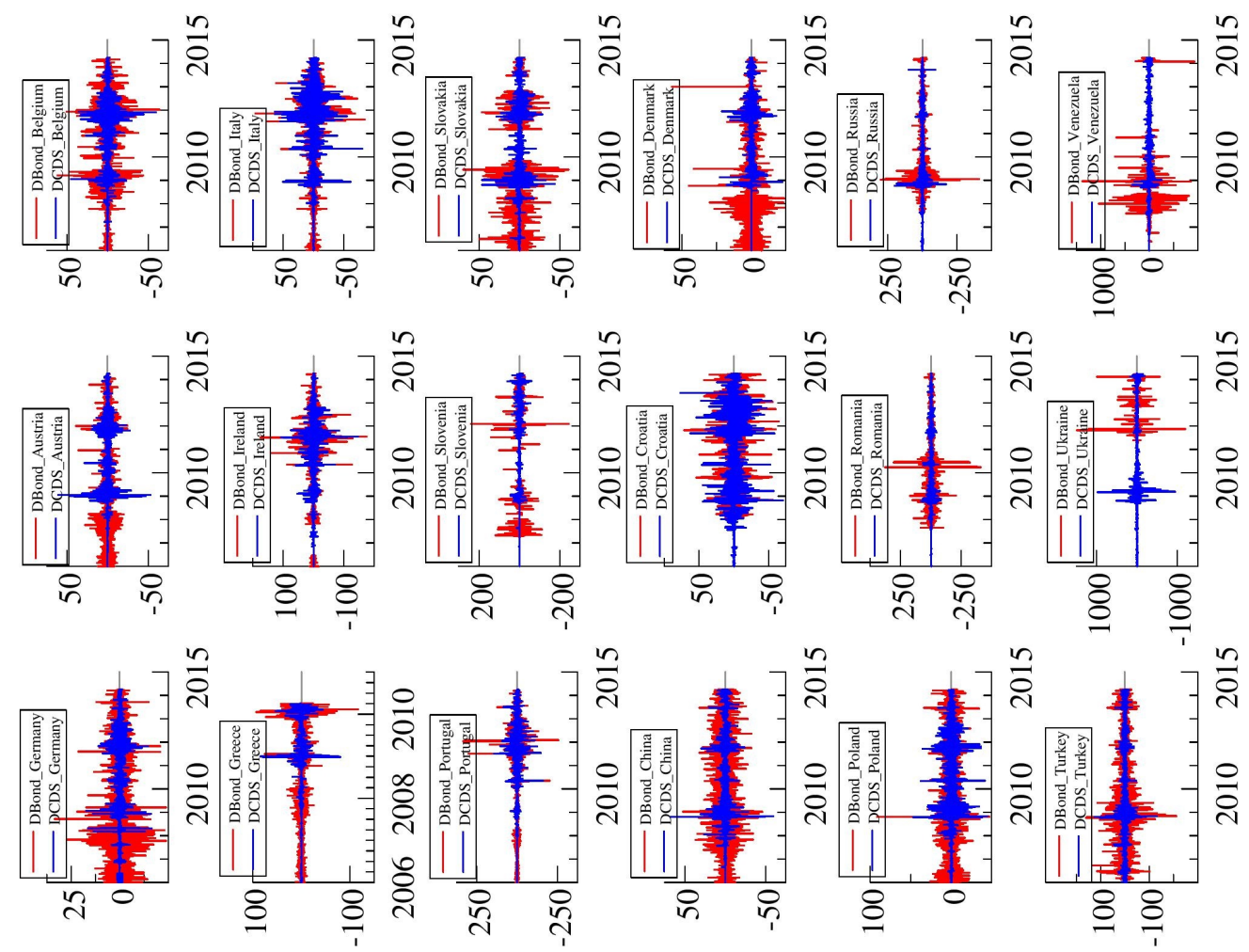


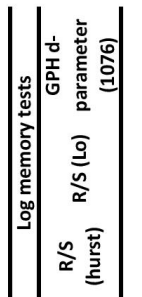

*

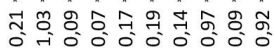

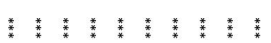

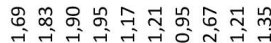

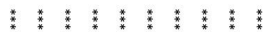
等

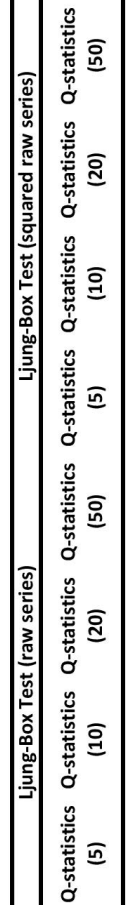

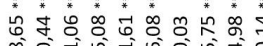

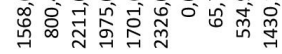

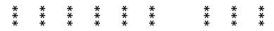

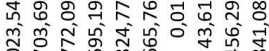

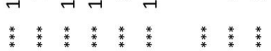

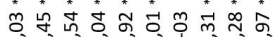

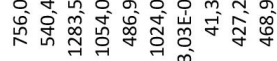

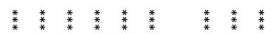
ชิㅇㅇㅇㅇ \&

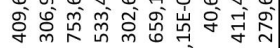

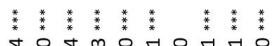

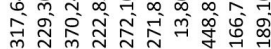

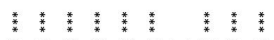
कo 앴

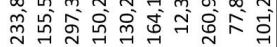

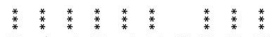
正

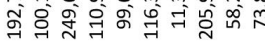

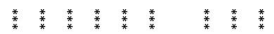

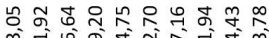

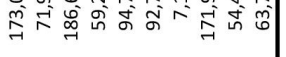

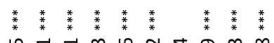

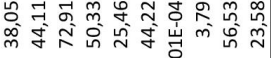

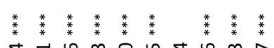

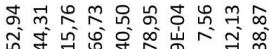

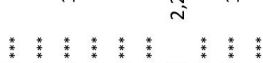

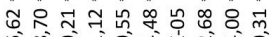

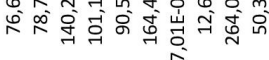

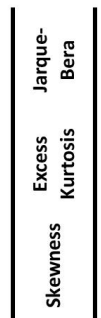

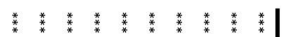

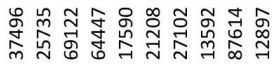

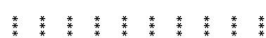

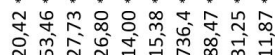

* * * * * * * * *

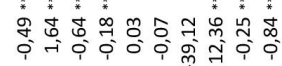

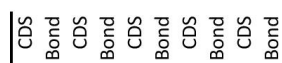

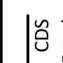

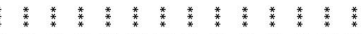

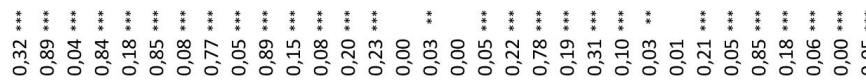

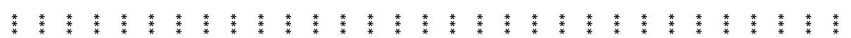

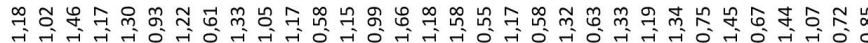

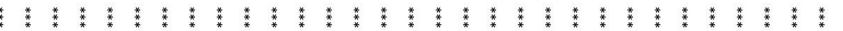

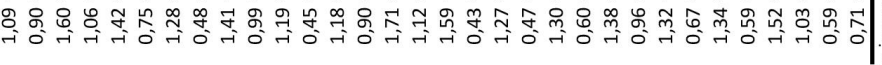

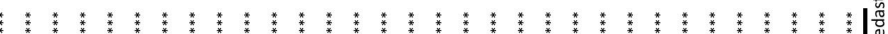
Ұ

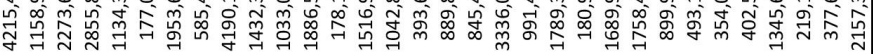

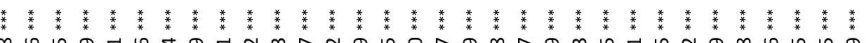

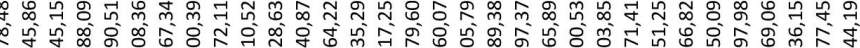

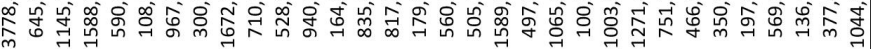

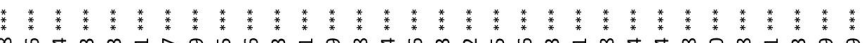

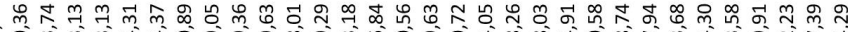

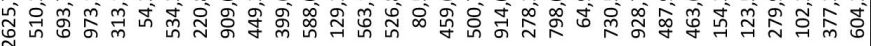

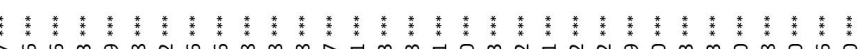

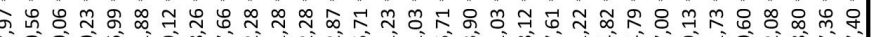

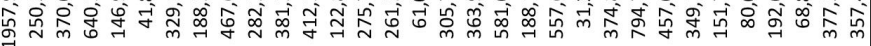

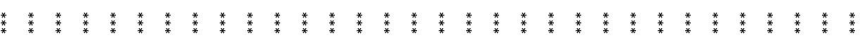

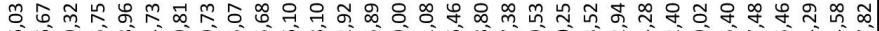

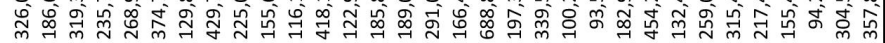

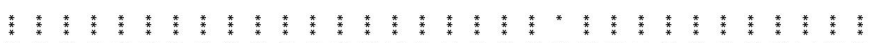

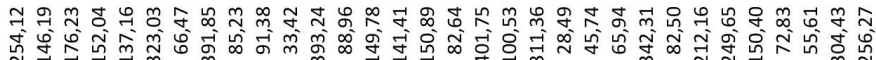

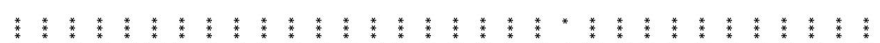

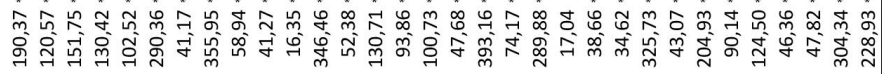

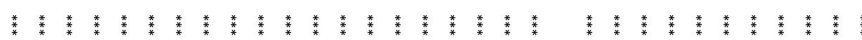

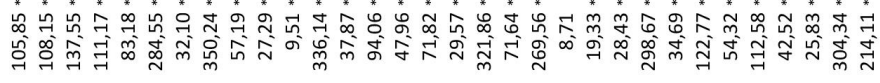
年

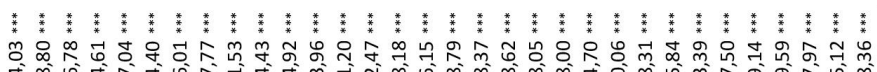

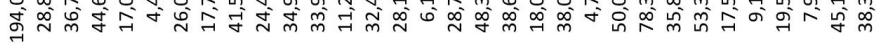

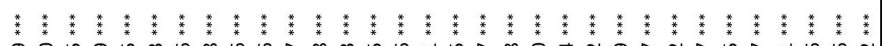

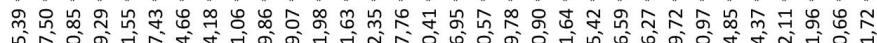

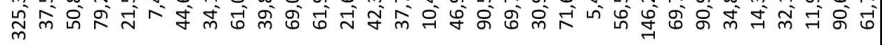

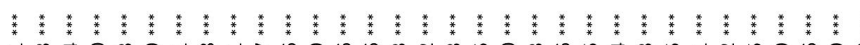

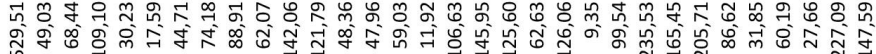
?

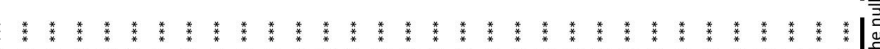

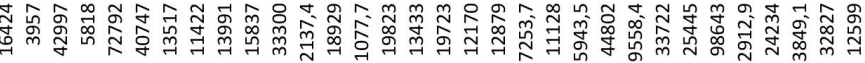

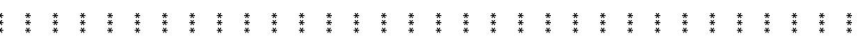

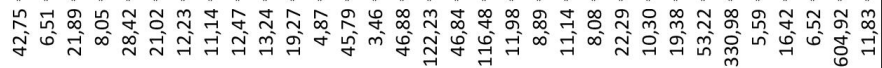

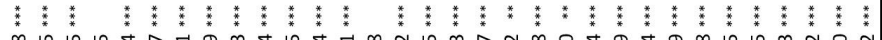

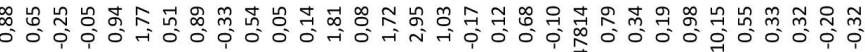

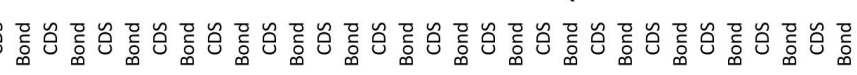

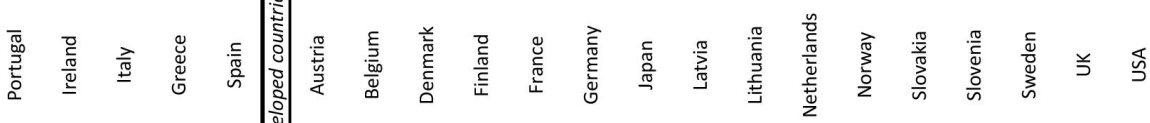
更

5 
舟

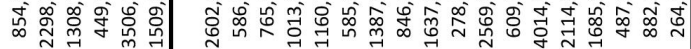

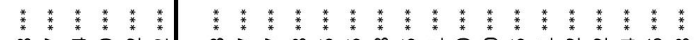

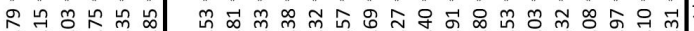

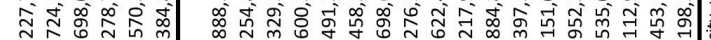

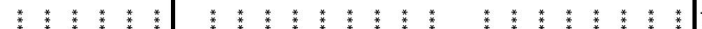

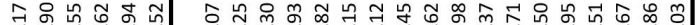

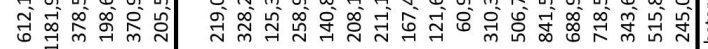

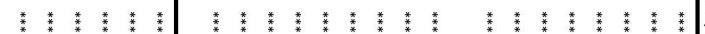

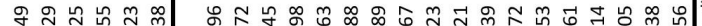

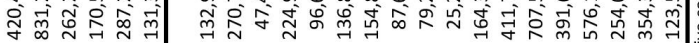

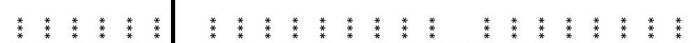

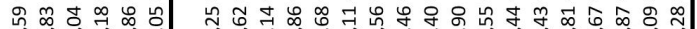

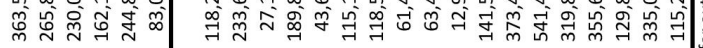

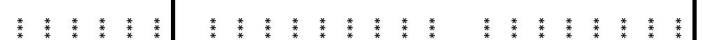

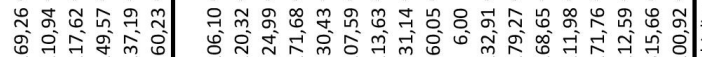

ब्্ન

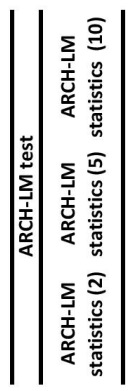

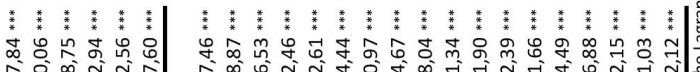

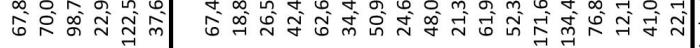

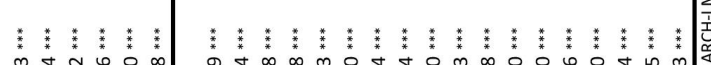

m

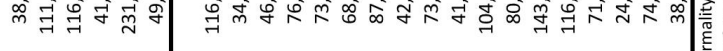

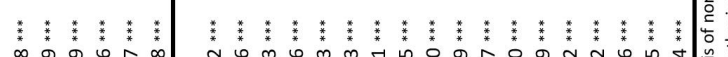

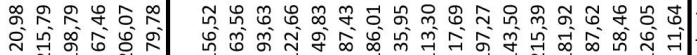

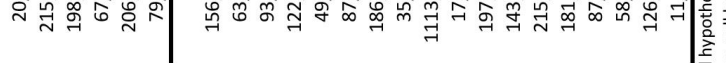

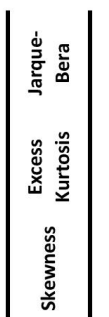

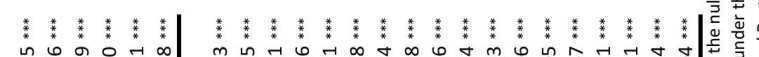

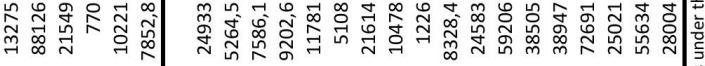

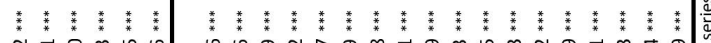

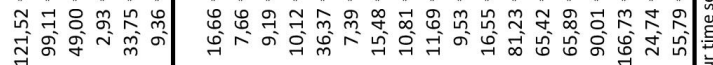

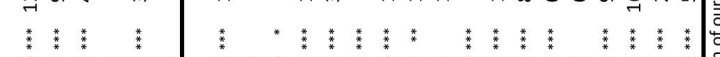

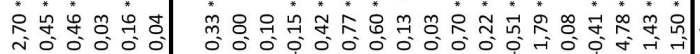

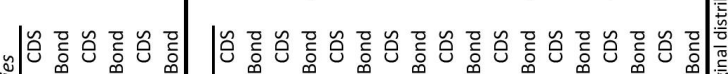

政

:

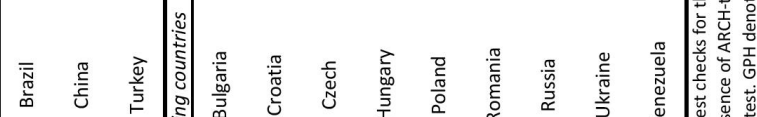


model estimation. Figure 2 displays the dynamic conditional correlation between the credit markets of each country, estimated by the AR(1)-FIEGARCH(1,d,1)-DCC model.

The time-varying correlations between the CDS ad the bond spreads of some constructed portfolios are presented in Figure 3. Graphs show a dissimilarity of the evolution dynamic of the DCCs between different portfolios, which is quite predictable given the notable difference between countries' credit risk levels. Focusing particularly on the most meaningful graphs of the PIIGS and the developed countries, we can clearly distinguish two correlation regimes: Before the Global Financial Crisis, correlations were at their lowest levels. With the occurrence of the first turmoil period in the financial markets, CDS and bond markets are becoming more correlated. This relationship is reinforced right after the outbreak of the European Debt crisis. The same conclusions are drawn for the time-varying countries' average correlation in Figure 4.

The pattern of the time-varing DCC can clearly be divided into four distinct phases. Before the first financial crisis, the level of correlations were low because of the weak demand on sovereign CDS contracts. Governments were still considered as riskless entities and international investors were not risk averse when it comes to sovereigns. By the end of 2007, financial markets in general started to feel some tension and the correlations became following an increasing trend. Some researchers and economics even argued that the increase in the average correlation is explained by the fact that the CDS trading conditions have worsened the crisis, impacting the credit cost. A third phase is detected after the outbreak of the European Debt Crisis characterized by a drastic increase in correlations due to the considerable number of speculative operations on sovereign CDS. The crisis effects are beginning to be felt and credit markets are suffering from a bullish phase because of the government's creditworthiness's decline. The consequences of the rescue operations adopted by the International Monetary Fund - among other organizations - are reflected in the decease of the credit markets' interactions during the fourth phase.

Based on the regressions results of Equation 7 (see Table 5), risk spillover is significantly detected in our studied countries. Credit risk markets in worldwide countries seem to interact during crisis periods. A significant increase in correlations are recorded in $21 \%$ of the studied countries during the first crisis and in $67 \%$ of the sample during the second crisis. This suggests that the European debt crisis's intensity and severity are more important than in the Global Financial Crisis. In fact, many countries around the world, that present a decoupling behavior (no significant interaction) during the credit crisis, become prone to contagion effects during the sovereign debt crisis (Italy, Spain, Austria, Turkey...). Although the CDS markets and the corresponding bond markets of the PIIGS countries are initially not interconnected during the first crisis, this dynamic has changed during the sovereign crisis where a reinforced links are observed (Except for Ireland). The same observations are made for Newly Industrialized countries and some developed and emerging countries. Meanwhile, whatever the period is, no contagion effects are noticed in credit markets of some countries such as Finland, Netherlands, Norway, Slovakia, the USA, Bulgaria, Czech, Romania and Venezuela, and this is in spite of the economic recession and financial instability of these countries. 


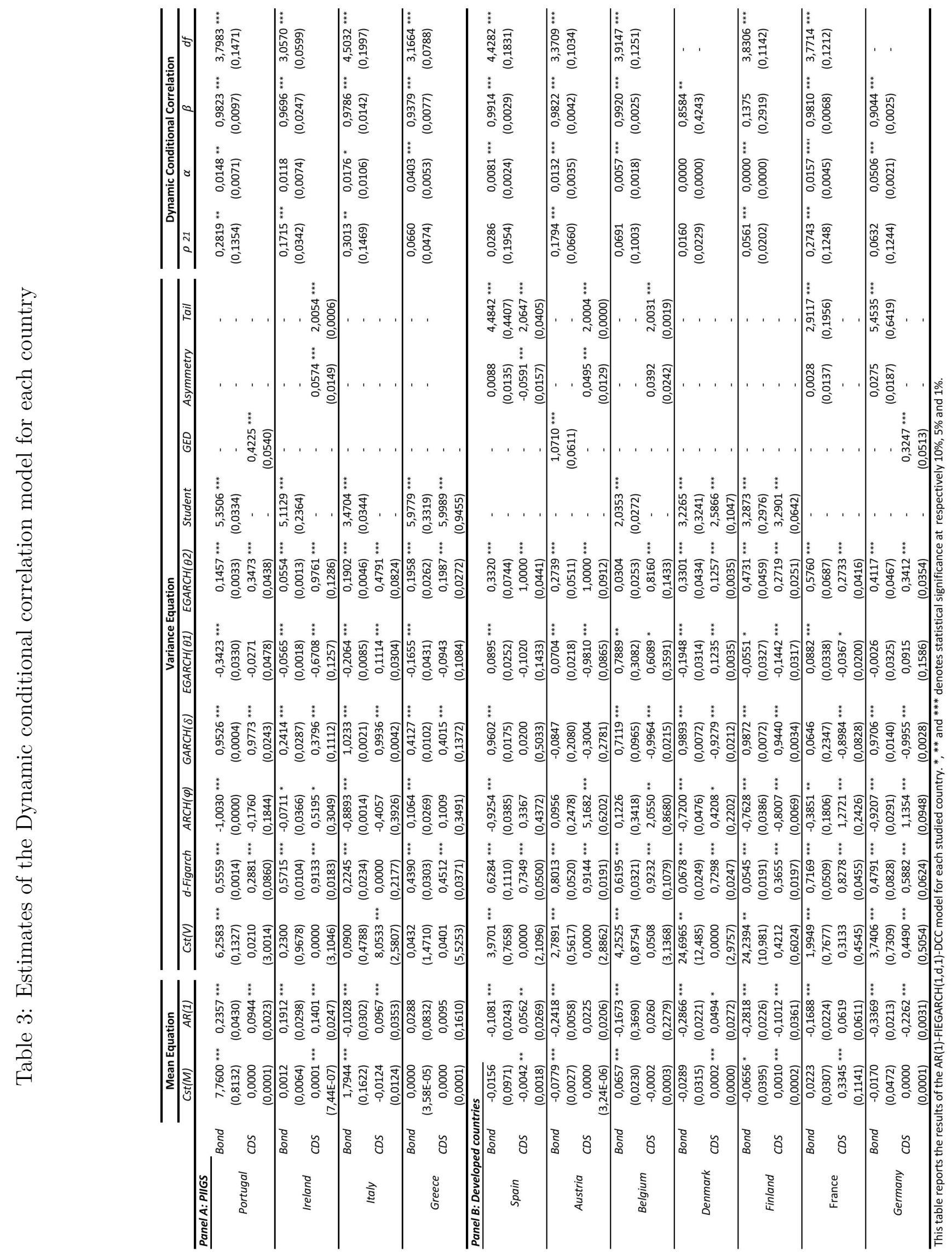




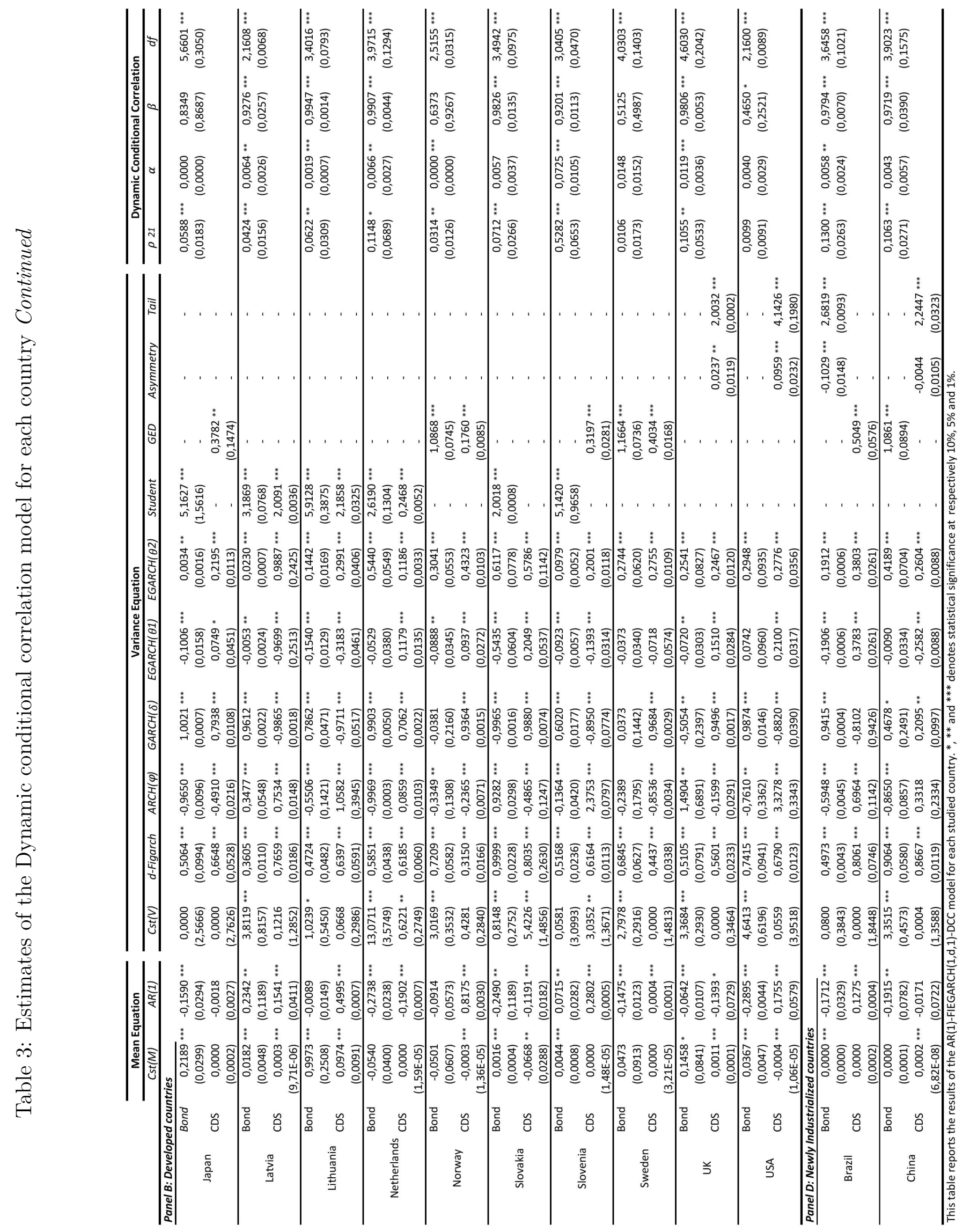




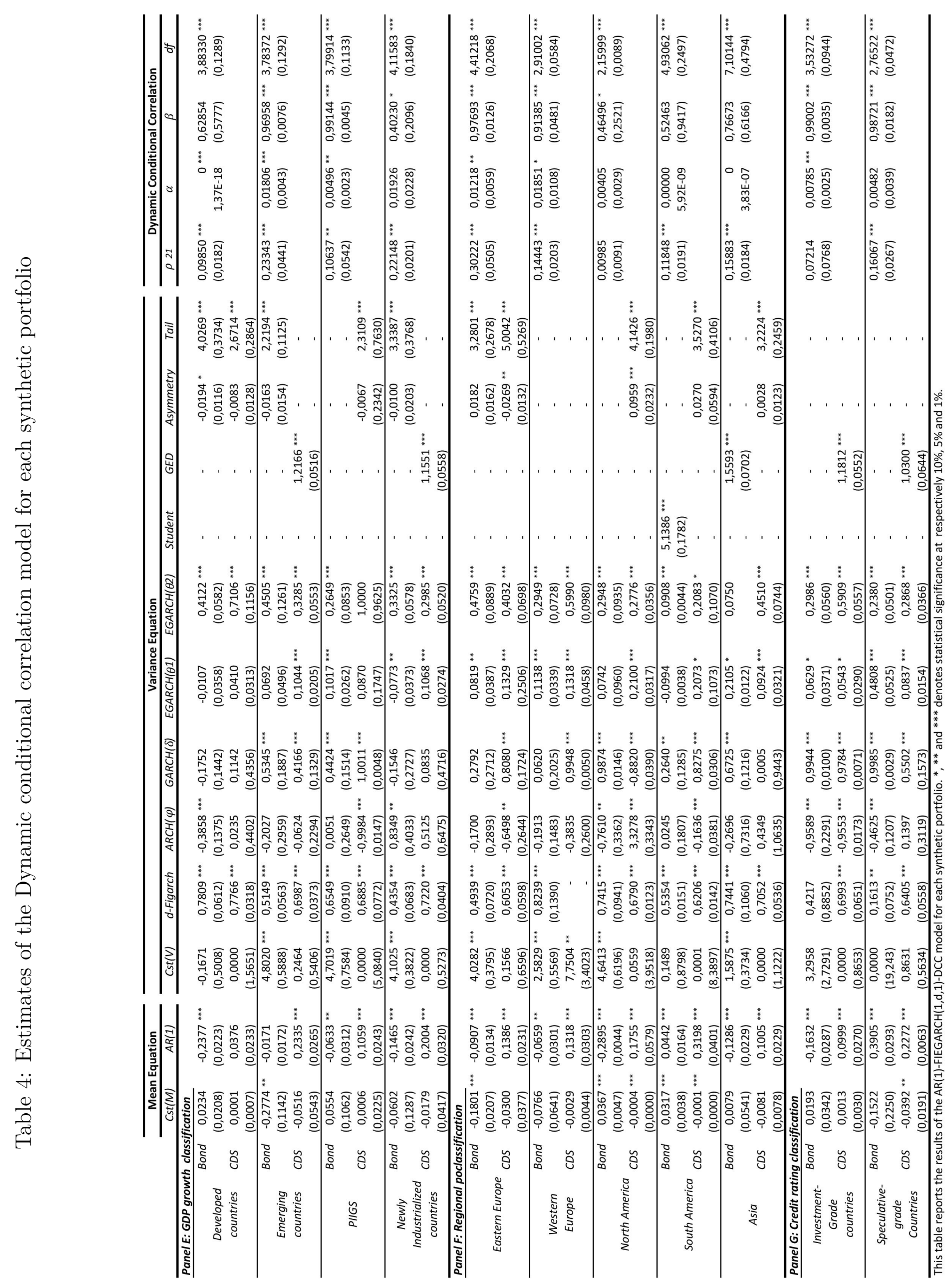




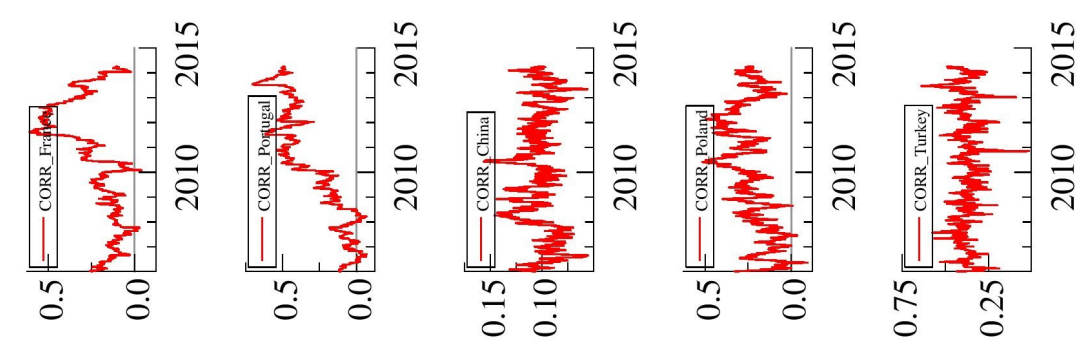

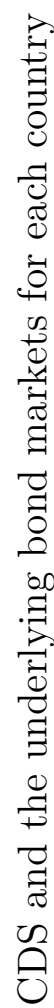
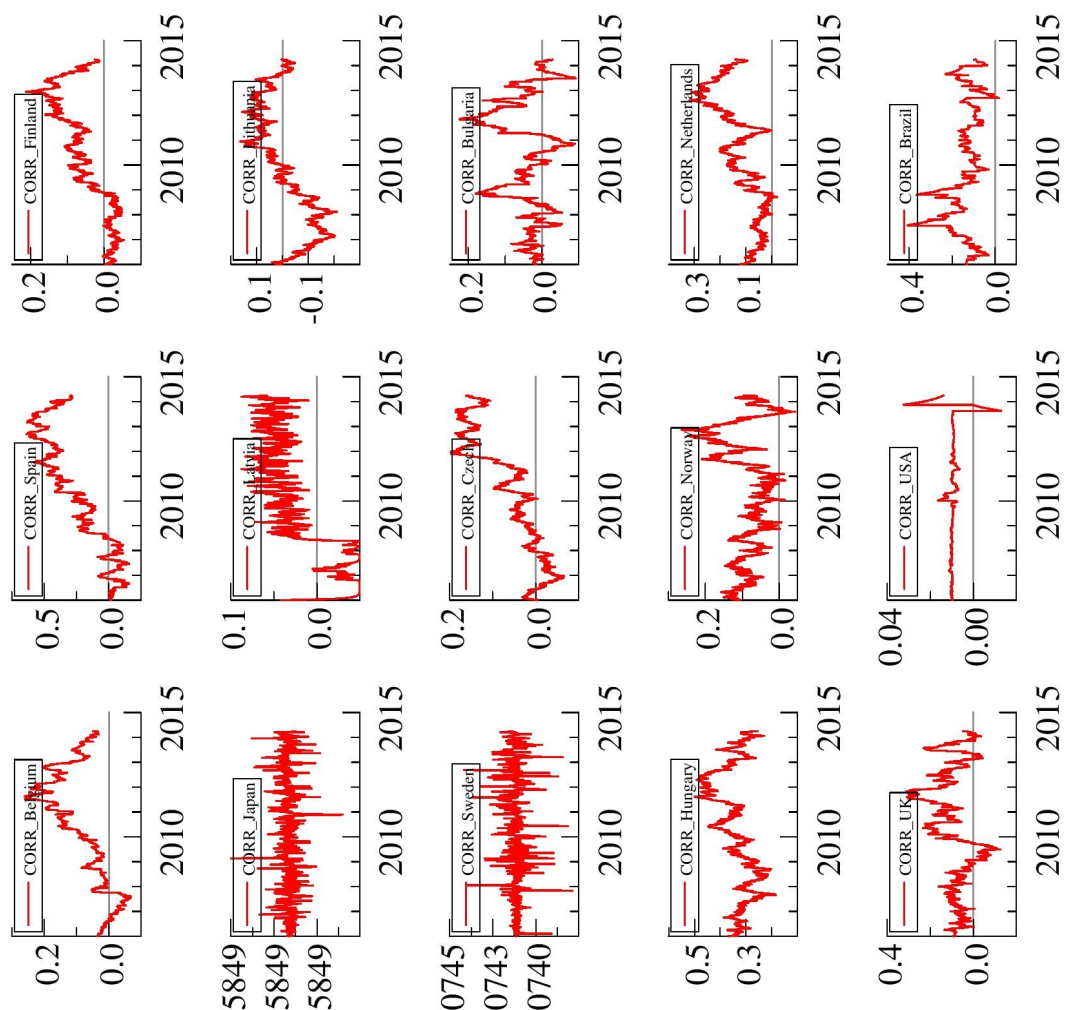

$\stackrel{\Xi}{ \pm}$
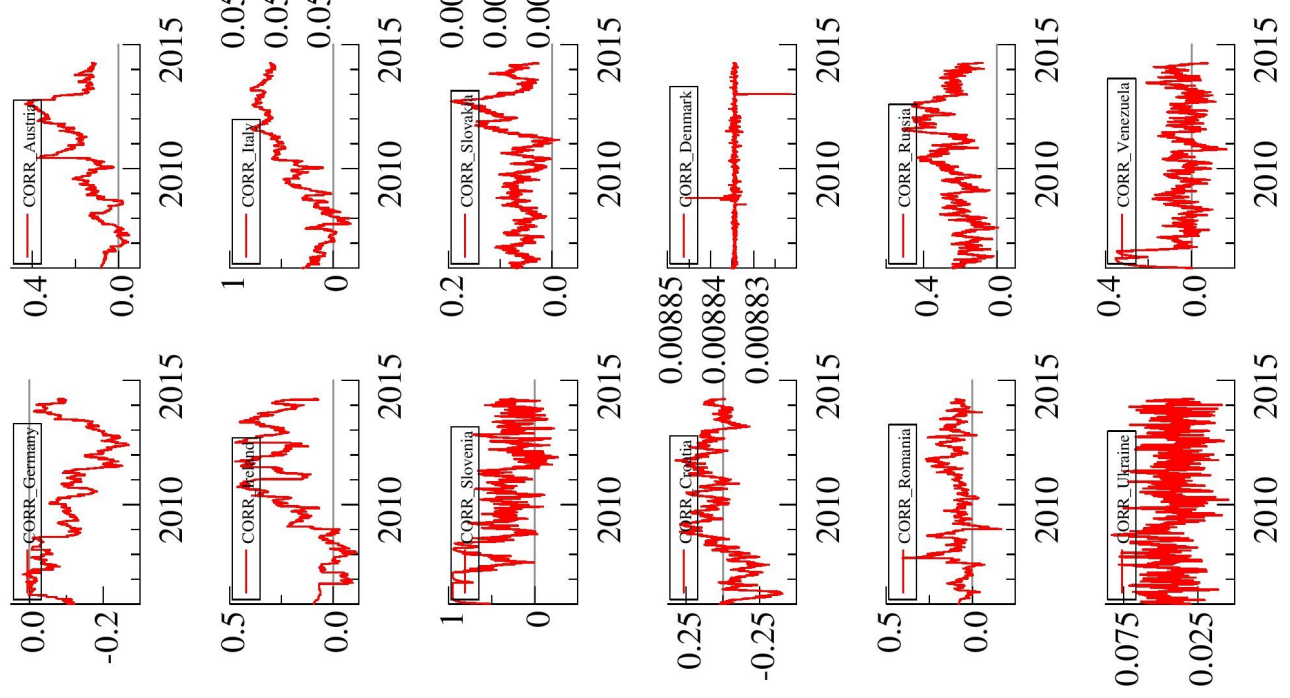

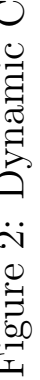



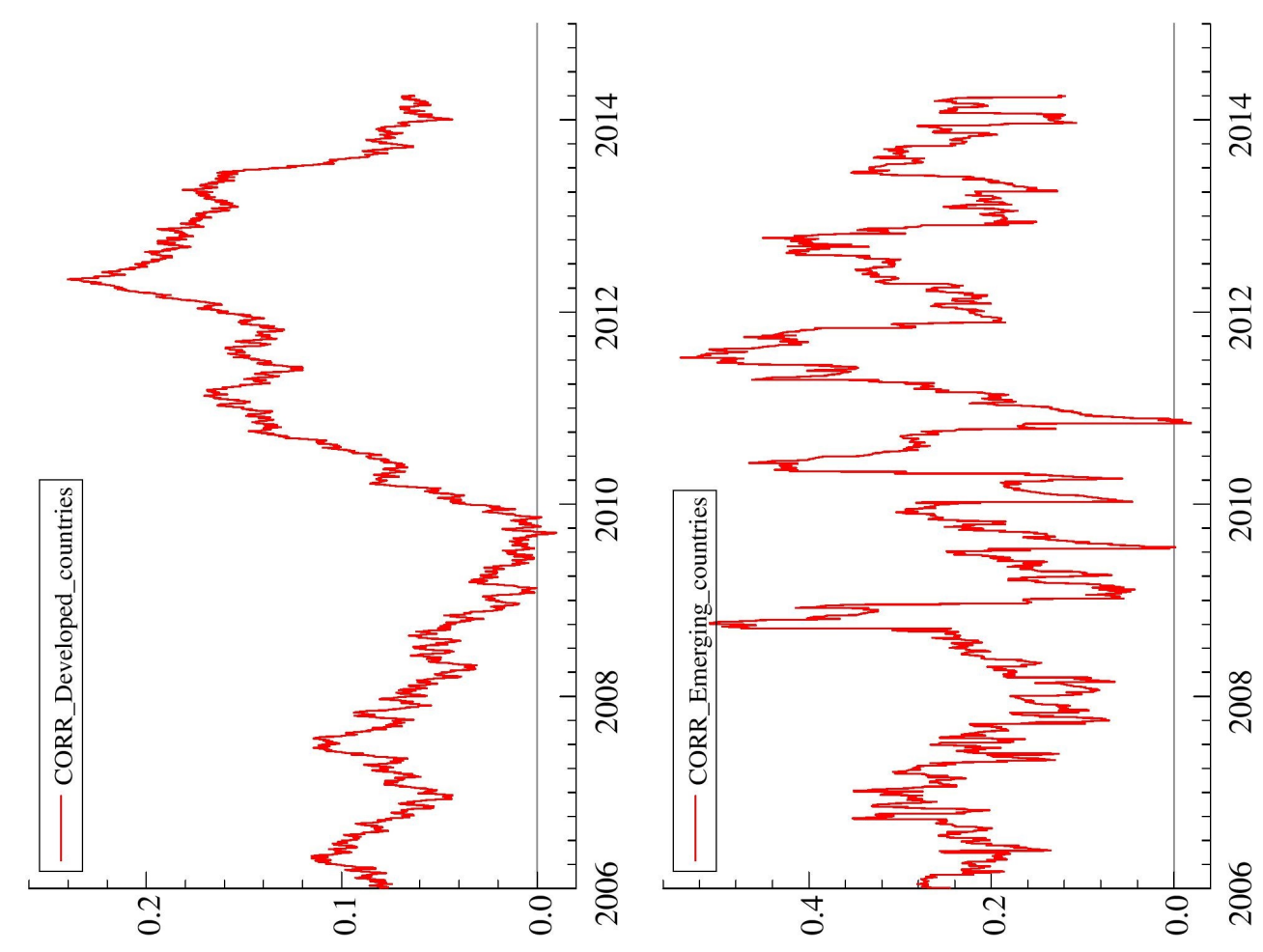

0
0
0
0
0
01
0
0

군

¿ొ

궁

苛

告

뭉

离

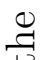

ซี

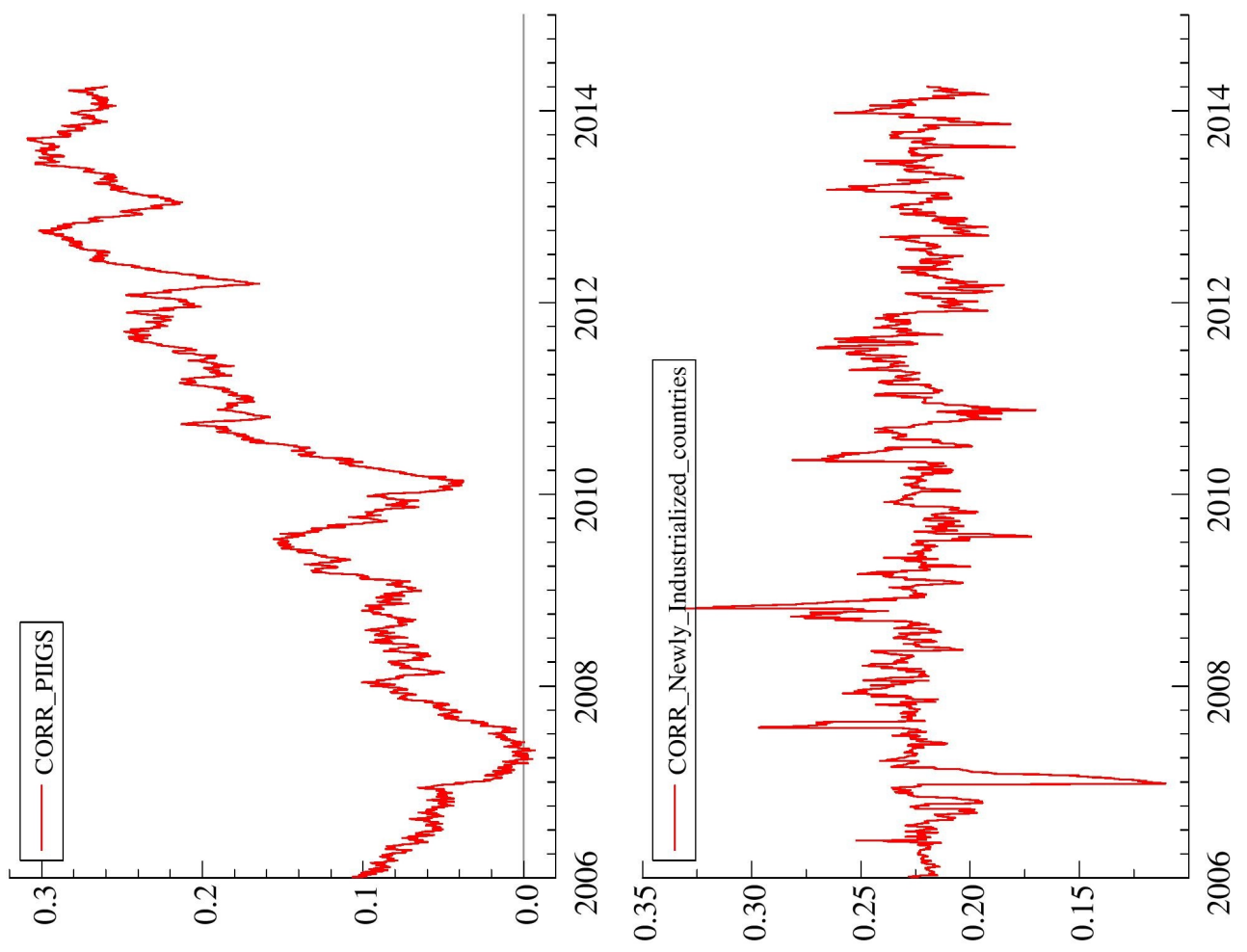

ฮิ

$\frac{9}{4}$

겅

竞

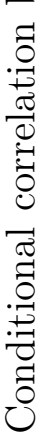

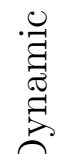

$\ddot{\circ}$. .

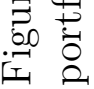


Synthetic portfolios' analysis show that the risk transmission among credit markets is present during both crises in the PIIGS and Asian countries' portfolios. Developed countries and newly industrialized countries' portfolios only exhibit spillover effects respectively during the sovereign crisis and the Financial crisis. Results of credit ratings classification portfolios are not conclusive.

In the second stage, and since risk spillover cannot only be detected by a significant increase in bivariate correlation, a Bayesian cointegrated VAR approach is used to model the interrelationship between the two credit markets. In order to capture small and extreme contagion effects, transformed data are used - instead of in levels or first-difference spreads - allowing to control for heteroscedasticity and serial correlation. Results of the 2 orders BVECM are presented upon request.

Transmission of financial shocks from one credit market to another within the same country is identified using the Granger Causality test. Table 6 reports the statistics of the Granger Causality test for each hypothesis.

Results of the full sample period show that the CDS market Granger-Causes the bond market in $16(49 \%)$ countries, while the bond market only impacts the CDS market in 9 $(27 \%)$ countries. Focusing on the constructed portfolio's analysis, the CDS spreads influence the borrowing cost only in Newly Industrialized countries, Eastern Europe and Asia. The bidirectional spillover effect is only detected in few countries, namely Italy, Ireland, Belgium and Romania. These results suggest that long-term equilibrium relationship between credit markets has an impact on the risk spillover.

The same Table presents the spillover results from the CDS markets to the bond markets and vice versa on different sub-periods. Evidences show that, during the tranquil period, there is a risk transmission from the CDS market to the Bond market in 37\% of cases while the reverse dynamic is only valid in $27 \%$ cases. The changes in investors risk appetite during crises made risk spillover effects occurring in further countries. There is a greater number of Granger Causality interrelationships between credit markets during the financial crisis and the sovereign crisis. In fact, the percentage of countries where the CDS volatility spills over the bond market increased from 37\% to 55\% during the global Financial Crisis and to $61 \%$ during the European debt crisis. The risk spillover percentage from the bond spreads to CDS spreads is, also, accentuated during the turmoil break but does not seem to follow a logical pattern. The bidirectional interaction degree dropped again to $33 \%$ during the post-crisis period.

Even though countries level analysis does not seem to coincide between the AR(1)FIEGARCH(1,d,1)-DCC ad the BVECM, the general interpretation remains the same. Contagion effects and risk spillovers are detected in sovereign credit markets with a reinforced phenomenon during crisis periods. 


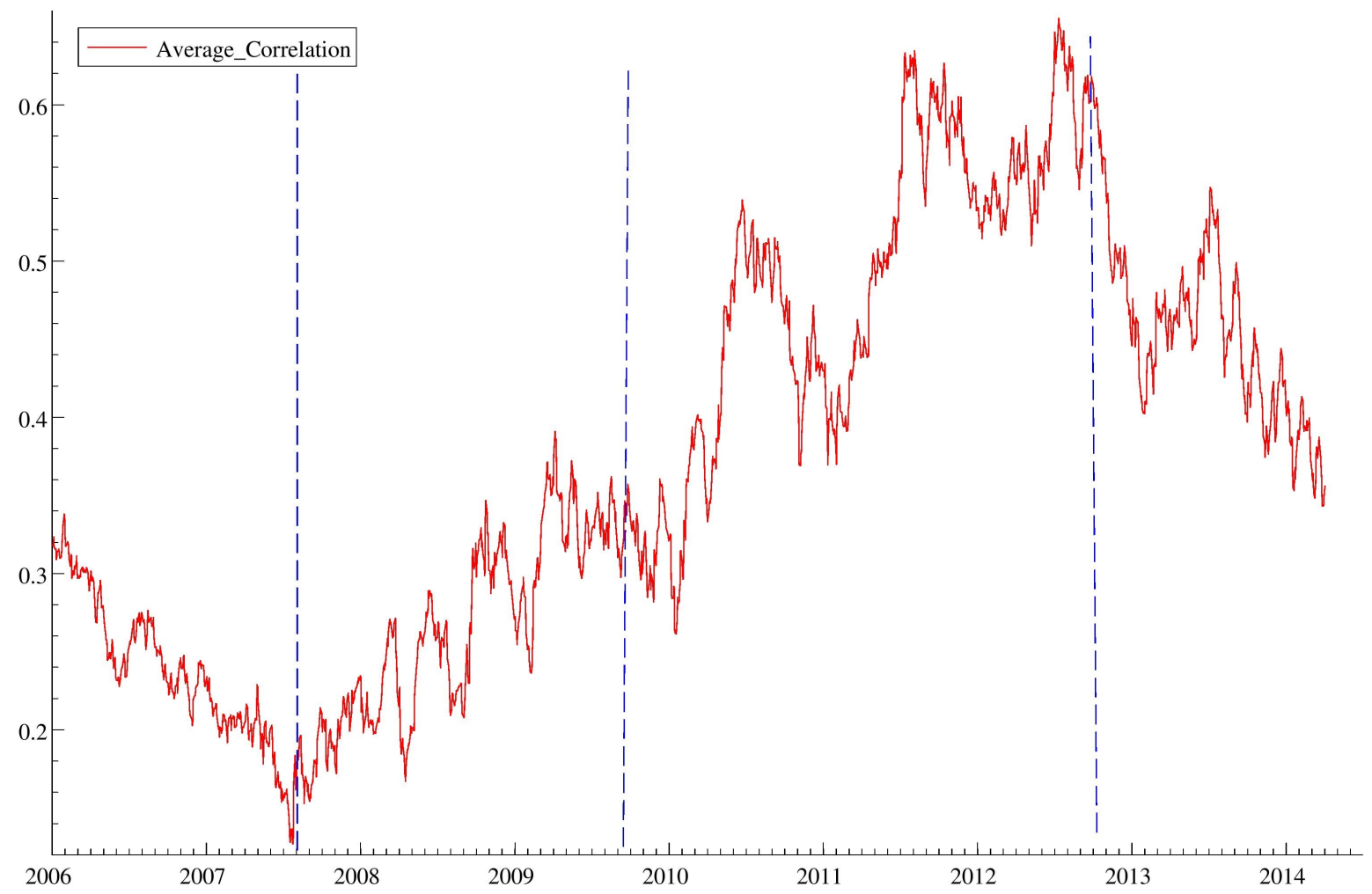

Figure 4: Average Dynamic Conditional correlation between the CDS and the corresponding bond markets of 33 countries 
Table 5: Dynamic Conditional Correlation Regressions Over Time

\begin{tabular}{|c|c|c|c|c|}
\hline & $\mu$ & $\bar{a} \_1$ & b_1 & b_2 \\
\hline \multicolumn{5}{|l|}{ Panel A: PIIGS } \\
\hline Portugal & $\begin{array}{c}0,98660 \cdots \\
(0,00314)\end{array}$ & $\begin{array}{r}0,00016 \\
(0,00075)\end{array}$ & $\begin{array}{r}0,00143 \\
(0,00092)\end{array}$ & $\begin{array}{r}0,00485 \cdots \\
(0,00127)\end{array}$ \\
\hline Ireland & $\begin{array}{c}0,99364 \\
(0,00244)\end{array}$ & $\begin{array}{r}0,00099 \\
(0,00063)\end{array}$ & $\begin{array}{r}-0,00054 \\
(0,00079)\end{array}$ & $\begin{array}{r}0,00105 \\
(0,00078)\end{array}$ \\
\hline Italy & $\begin{array}{c}0,99233 \\
(0,00247)\end{array}$ & $\begin{array}{r}0,00008 \\
(0,00100)\end{array}$ & $\begin{array}{r}0,00148 \\
(0,00110)\end{array}$ & $\begin{array}{c}0,00332 * * \\
(0,00135)\end{array}$ \\
\hline Greece & $\begin{array}{c}0,77180^{* * *} \\
(0,01372)\end{array}$ & $\begin{array}{l}-0,22820^{* * *} \\
(0,01373)\end{array}$ & $\begin{array}{r}1,03 E-06 \\
(0,00069)\end{array}$ & $\begin{array}{l}0,00225 \\
(0,00069)\end{array}$ \\
\hline Spain & $\begin{array}{c}0,99225 \\
(0,00249)\end{array}$ & $\begin{array}{r}-0,00026 \\
(0,00076)\end{array}$ & $\begin{array}{r}0,00083 \\
(0,00092)\end{array}$ & $\begin{array}{c}0,00292 * * \\
(0,00114)\end{array}$ \\
\hline \multicolumn{5}{|c|}{ Panel B: Developed countries } \\
\hline Austria & $\begin{array}{c}0,99608 * * * \\
(0,00179)\end{array}$ & $\begin{array}{r}0,00023 \\
(0,00038)\end{array}$ & $\begin{array}{r}0,00032 \\
(0,00046)\end{array}$ & $\begin{array}{l}0,00095 * * \\
(0,00047)\end{array}$ \\
\hline Belgium & $\begin{array}{c}0,99619 \\
(0,00165)\end{array}$ & $\begin{array}{c}0,00000 \text { ** } \\
(0,00017)\end{array}$ & $\begin{array}{r}0,00027 \\
(0,00023)\end{array}$ & $\begin{array}{l}0,00076 \text { *** } \\
(0,00028)\end{array}$ \\
\hline Denmark & $\begin{array}{c}0,13644 \\
(0,02138)\end{array}$ & $\begin{array}{c}0,00763 \cdots \\
(0,00019)\end{array}$ & $\begin{array}{r}2,19 \mathrm{E}-08 \\
(0,00000)\end{array}$ & $\begin{array}{l}-3,91 E-08 \\
(0,00000)\end{array}$ \\
\hline Finland & $\begin{array}{l}0,99845 * * * \\
(0,00128)\end{array}$ & $\begin{array}{r}-0,00003 \\
(0,00013)\end{array}$ & $\begin{array}{r}0,00018 \\
(0,00019)\end{array}$ & $\begin{array}{r}0,00024 \\
(0,00018)\end{array}$ \\
\hline France & $\begin{array}{c}0,99643 \cdots * \\
(0,00181)\end{array}$ & $\begin{array}{r}0,00017 \\
(0,00058)\end{array}$ & $\begin{array}{r}0,00049 \\
(0,00063)\end{array}$ & $\begin{array}{c}0,00153 \text { ** } \\
(0,00061)\end{array}$ \\
\hline Germany & $\begin{array}{c}0,96609 * * * \\
(0,00177)\end{array}$ & $\begin{array}{r}-0,00019 \\
(0,00025)\end{array}$ & $\begin{array}{r}-0,00016 \\
(0,00028)\end{array}$ & $\begin{array}{c}-0,00056 * \\
(0,00029)\end{array}$ \\
\hline Japan & $\begin{array}{c}0,80238 \\
(0,01287)\end{array}$ & $\begin{array}{c}0,01156 \\
(0,00075)\end{array}$ & $\begin{array}{l}-2,22 \mathrm{E}-08 \text { * } \\
(1,23 \mathrm{E}-08)\end{array}$ & $\begin{array}{r}-1,02 \mathrm{E}-08 \\
(1,21 \mathrm{E}-08)\end{array}$ \\
\hline Latvia & $\begin{array}{c}0,98514 \\
(0,00349)\end{array}$ & $\begin{array}{c}-0,00086 \\
(0,00028)\end{array}$ & $\begin{array}{c}0,00097 * * * \\
(0,00031)\end{array}$ & $\begin{array}{c}0,00062 * \\
(0,00026)\end{array}$ \\
\hline Lithuania & $\begin{array}{c}0,997966^{* *} \\
(0,00142)\end{array}$ & $\begin{array}{l}-0,00034 \text { ** } \\
(0,00016)\end{array}$ & $\begin{array}{c}0,00045 * \\
(0,00026)\end{array}$ & $\begin{array}{c}0,00063 * * \\
(0,00027)\end{array}$ \\
\hline Netherlands & 0,99676 ** & $\begin{array}{r}-0,00005 \\
0,00029\end{array}$ & $\begin{array}{r}0,00035 \\
\end{array}$ & $\begin{array}{r}0,00027 \\
(0,00031)\end{array}$ \\
\hline Norway & $\begin{array}{c}(0,00184) \\
0,99510 \cdots \\
(0,00214)\end{array}$ & $\begin{array}{r}(0,00029) \\
0,00041 \\
(0,00039)\end{array}$ & $\begin{array}{l}(0,00002) \\
-4,01 E-05 \\
(0,00030)\end{array}$ & $\begin{array}{r}(0,000 E-05 \\
8,26-05 \\
(0,00026)\end{array}$ \\
\hline Slovakia & $\begin{array}{l}0,99343 \\
(0,00252)\end{array}$ & $\begin{array}{r}0,00034 \\
(0,00029)\end{array}$ & $\begin{array}{r}6,76 E-05 \\
(0,00028)\end{array}$ & $\begin{array}{r}7,03 E-05 \\
(0,00020)\end{array}$ \\
\hline Slovenia & $\begin{array}{c}0,97722 \cdots \\
(0,00445)\end{array}$ & $\begin{array}{c}0,02248 \\
(0,00485)\end{array}$ & $\begin{array}{l}-0,01188 * * * \\
(0,00356)\end{array}$ & $\begin{array}{l}-0,00520 * * \\
(0,00242)\end{array}$ \\
\hline Sweden & $\begin{array}{c}0,80467 \\
(0,01281)\end{array}$ & $\begin{array}{l}0,00145^{* * *} \\
(0,00009)\end{array}$ & $\begin{array}{r}-7,29 \mathrm{E}-09 \\
(21,40 \mathrm{E}-08)\end{array}$ & $\begin{array}{c}2,70 \mathrm{E}-07 \text { ** } \\
(14,65 \mathrm{E}-08)\end{array}$ \\
\hline UK & $\begin{array}{c}0,98485 \cdots * \\
(0,00359)\end{array}$ & $\begin{array}{c}0,00104 \text { ** } \\
(0,00044)\end{array}$ & $\begin{array}{r}-0,00064 \\
(0,00057)\end{array}$ & $\begin{array}{c}0,00161 \cdots \\
(0,00064)\end{array}$ \\
\hline USA & $\begin{array}{c}0,97858 \cdots * \\
(0,00446)\end{array}$ & $\begin{array}{c}0,00022 * * * \\
(0,00005)\end{array}$ & $\begin{array}{r}-5,12 \mathrm{E}-05 \\
(43,74 \mathrm{E}-06)\end{array}$ & $\begin{array}{r}-1,33 \mathrm{E}-05 \\
(43,35 \mathrm{E}-06)\end{array}$ \\
\hline \multicolumn{5}{|c|}{ Panel C: Newly Industrialized Countries } \\
\hline Brazil & $\begin{array}{c}0,98784 \\
(0,00355)\end{array}$ & $\begin{array}{c}0,00126 \\
(0,00063)\end{array}$ & $\begin{array}{r}0,00101 \\
(0,00070)\end{array}$ & $\begin{array}{l}-0,00087 \\
(0,00052)\end{array}$ \\
\hline China & $\begin{array}{c}0,97906 \cdots * \\
(0,00432)\end{array}$ & $\begin{array}{c}0,00196 \\
(0,00042)\end{array}$ & $\begin{array}{c}0,00033 * * \\
(0,00017)\end{array}$ & $\begin{array}{c}0,00028 * \\
(0,00016)\end{array}$ \\
\hline Turkey & $\begin{array}{c}0,92741, * * \\
(0,00811)\end{array}$ & $\begin{array}{c}0,028333^{* * *} \\
(0,00324) \\
\end{array}$ & $\begin{array}{r}-0,00036 \\
(0,00122) \\
\end{array}$ & $\begin{array}{c}-0,00240 * * \\
(0,00124) \\
\end{array}$ \\
\hline \multicolumn{5}{|c|}{ Panel D: Emerging countries } \\
\hline Bulgaria & $\begin{array}{c}0,99393 \\
(0,00236)\end{array}$ & $\begin{array}{r}0,00002 \\
(0,00023)\end{array}$ & $\begin{array}{r}0,00026 \\
(0,00035)\end{array}$ & $\begin{array}{r}0,00045 \\
(0,00035)\end{array}$ \\
\hline Croatia & $\begin{array}{c}0,99287^{* * *} \\
(0,00241)\end{array}$ & $\begin{array}{r}-0,00062 \\
(0,00047)\end{array}$ & $\begin{array}{c}0,00131 \text { * } \\
(0,00076)\end{array}$ & $\begin{array}{c}0,00148 \text { * } \\
(0,00081)\end{array}$ \\
\hline Czech & $\begin{array}{c}0,99819 \\
(0,00123)\end{array}$ & $\begin{array}{r}-0,00013 \\
(0,00015)\end{array}$ & $\begin{array}{r}0,00026 \\
(0,00018)\end{array}$ & $\begin{array}{r}0,00017 \\
(0,00018)\end{array}$ \\
\hline Hungary & $\begin{array}{c}0,99393 \\
(0,00225)\end{array}$ & $\begin{array}{l}0,00173 \text { ** } \\
(0,00079)\end{array}$ & $\begin{array}{r}0,00006 \\
(0,00030)\end{array}$ & $\begin{array}{l}0,00093 * * * \\
(0,00029)\end{array}$ \\
\hline Poland & $\begin{array}{c}0,98838 \cdots * \\
(0,00299)\end{array}$ & $\begin{array}{c}0,00163{ }^{* *} \\
(0,00072)\end{array}$ & $\begin{array}{r}0,00108 \\
(0,00072)\end{array}$ & $\begin{array}{c}0,00249 \cdots \\
(0,00083)\end{array}$ \\
\hline Romania & $0,97267 * * *$ & $0,00203 * * *$ & 0,00069 & 0,00062 \\
\hline Russia & $\begin{array}{r}(0,00500) \\
0,99064 * * *\end{array}$ & $\begin{array}{c}(0,00063) \\
0,00170 \text { ** }\end{array}$ & $\begin{array}{r}(0,00081) \\
0,00011\end{array}$ & $\begin{array}{c}(0,00080) \\
0,00137 \\
\quad *\end{array}$ \\
\hline Ukraine & $0,93130 \ldots$ & $\begin{array}{c}(0,00077) \\
0,00318 \cdots \\
(0,00046)\end{array}$ & $\begin{array}{r}(0,00064) \\
0,00005\end{array}$ & $-0,00053$ ** \\
\hline Venezuela & $\begin{array}{c}0,98420 \\
(0,00374)\end{array}$ & $\begin{array}{c}(0,00046) \\
0,00348 * * * \\
(0,00108)\end{array}$ & $\begin{array}{c}-0,00292 * * * \\
(0,00109)\end{array}$ & $\begin{array}{r}(0,00004) \\
-0,00018 \\
(0,00060)\end{array}$ \\
\hline
\end{tabular}

\begin{tabular}{|c|c|c|c|c|}
\hline & $\mu$ & a_1 & b_1 & b_2 \\
\hline \multicolumn{5}{|c|}{ Panel E: GDP growth classification } \\
\hline Developed countries & $\begin{array}{c}0,99716 \ldots \\
(0,00126)\end{array}$ & $\begin{array}{r}0,00022 \\
(0,00018)\end{array}$ & $\begin{array}{r}-0,00017 \\
(0,00018)\end{array}$ & $\begin{array}{l}0,00037 \text { ** } \\
(0,00016)\end{array}$ \\
\hline Emerging countries & $\begin{array}{c}0,98252 \\
(0,00407)\end{array}$ & $\begin{array}{c}0,00438 \text { *** } \\
(0,00146)\end{array}$ & $\begin{array}{r}-0,00102 \\
(0,00127)\end{array}$ & $\begin{array}{r}0,00128 \\
(0,00090)\end{array}$ \\
\hline PIIGS & $\begin{array}{l}0,996977^{\cdots *} \\
(0,00127)\end{array}$ & $\begin{array}{r}-0,00016 \\
(0,00021)\end{array}$ & $\begin{array}{c}0,00049 \text { ** } \\
(0,00023)\end{array}$ & $\begin{array}{l}0,00046 \text { ** } \\
(0,00023)\end{array}$ \\
\hline $\begin{array}{l}\text { Newly Industrialized } \\
\text { countries }\end{array}$ & $\begin{array}{l}0,94373 * * * \\
(0,00710)\end{array}$ & $\begin{array}{l}0,01173^{* * *} \\
(0,00154)\end{array}$ & $\begin{array}{l}1,19 \mathrm{E}-03 \text { *** } \\
(0,00045)\end{array}$ & $\begin{array}{r}-0,00036 \\
(0,00030)\end{array}$ \\
\hline \multicolumn{5}{|c|}{ Panel F: Regional classification } \\
\hline Eastern Europe & $\begin{array}{c}(0,99407) \\
0,00246\end{array}$ & $\begin{array}{c}(0,00238) * * \\
0,00103\end{array}$ & $\begin{array}{r}-(0,00045) \\
0,00057\end{array}$ & $\begin{array}{r}-(0,00009) \\
0,00039\end{array}$ \\
\hline Western Europe & $\begin{array}{c}0,983644^{* * *} \\
(0,00396)\end{array}$ & $\begin{array}{l}0,00215, \cdots * \\
(0,00071)\end{array}$ & $\begin{array}{r}-0,00039 \\
(0,00057)\end{array}$ & $\begin{array}{c}0,00111 \text { ** } \\
(0,00048)\end{array}$ \\
\hline North America & $\begin{array}{c}0,97858 \text { *** } \\
(0,00446)\end{array}$ & $\begin{array}{c}0,00022 \\
(0,00005)\end{array}$ & $\begin{array}{r}-0,00005 \\
(0,00004)\end{array}$ & $\begin{array}{r}-0,00001 \\
(0,00004)\end{array}$ \\
\hline South America & $\begin{array}{c}0,728577^{\cdots *} \\
(0,01478)\end{array}$ & $\begin{array}{r}0,03187 \\
(0,00200)\end{array}$ & $\begin{array}{l}3,39 \mathrm{E}-03 * * * \\
(0,00118)\end{array}$ & $\begin{array}{l}-6,68 \mathrm{E}-04 \\
(0,00080)\end{array}$ \\
\hline Asia & $\begin{array}{l}0,47236^{* * *} \\
(0,01902)\end{array}$ & $\begin{array}{l}0,083822^{* * *} \\
(0,00302)\end{array}$ & $\begin{array}{c}0,00000 \text { ** } \\
(10,99 \mathrm{E}-12)\end{array}$ & $\begin{array}{c}0,00000 \text { * } \\
(7,46 \mathrm{E}-12)\end{array}$ \\
\hline \multicolumn{5}{|c|}{ Panel G: Credit rating classification } \\
\hline $\begin{array}{l}\text { Investment grade } \\
\text { countries }\end{array}$ & $\begin{array}{c}0,99575 \ldots \\
(0,00194)\end{array}$ & $\begin{array}{r}-0,00012 \\
(0,00044)\end{array}$ & $\begin{array}{r}0,00021 \\
(0,00052)\end{array}$ & $\begin{array}{r}0,00078 \\
(0,00050)\end{array}$ \\
\hline $\begin{array}{l}\text { Speculative grade } \\
\text { countries }\end{array}$ & $\begin{array}{l}0,99143 \\
(0,00286)\end{array}$ & $0,001511^{* * *}$ & $\begin{array}{r}0,00002 \\
0,00023)\end{array}$ & o, \\
\hline
\end{tabular}

of the GFC and the dummy variable of the EDC. Values in parentheses depict standard deviation.

$*{ }^{* *}$ and ${ }^{* * *}$ denotes statistical significance at respectively $10 \%, 5 \%$ and $1 \%$. 


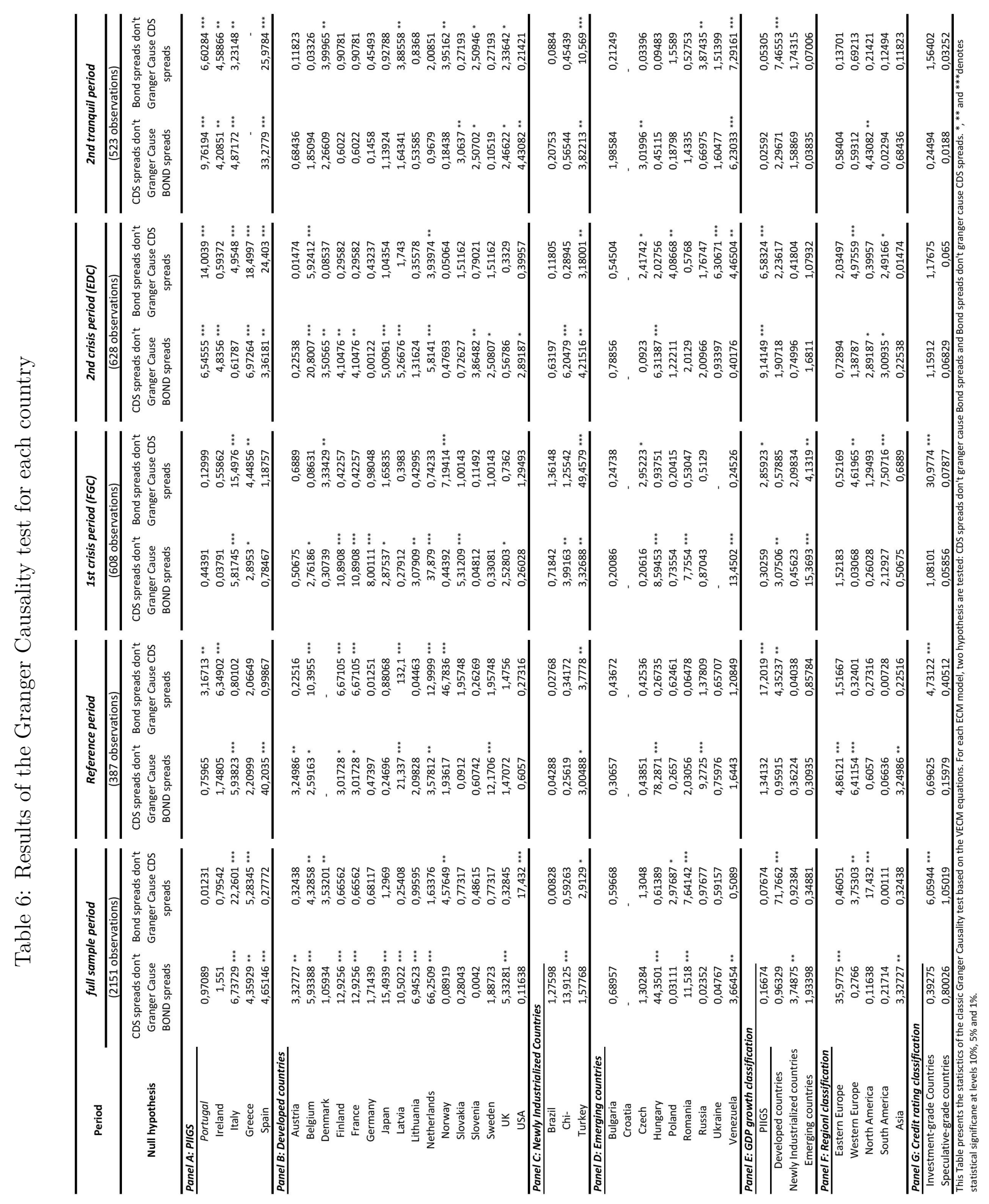




\subsection{Financial and economic implications}

Our results are relevant to both portfolio managers and policymakers. From the one hand, the time-varying cross-market behavior is an accurate indicator of financial stability. We show that after the outbreak of the Financial Global Crisis and the European Debt crisis, credit markets exhibit contagion effects and risk spillovers between CDS market and the corresponding bond market in a unidirectional or bidirectional depending on the country. National policymakers should, thus, put in place regulatory economic policies for countries presenting systemic risk. Furthermore, in some countries, crises in the bond market should be anticipated right after the occurrence of a financial shock in the CDS market and vice versa, if ever the shock shows up in one market and yet doesn't show up in the other one. Consequently, appropriate regulative solutions should be taken at the right moment to stop the propagation of such phenomenon.

On the other hand, credit markets' participants could, as well, take advantages of our findings. They could potentially adjust their trading operations depending on the co-movement dynamics of the CDS and the bond market. First, since credit assets' prices are highly correlated in some countries, portfolio managers could speculate on the predictability of the borrowing cost by following the evolution of the CDS spreads over time. Second, our results reveal that the studied credit markets present heterogeneous characteristics that could benefit to financial traders by investing in a diversified portfolio of worldwide countries combinations. Third, our findings show that the risk spillover mechanism is changing overtime and across countries. This should be taken into consideration by credit risk managers while elaborating their constantly evolving hedging positions. Yet, arbitrage opportunities could be detected by focusing on whether the country is prone to contagion phenomena or not.

\section{Conclusion}

This paper gives further evidences of risk spillover on credit markets in an international context. The time-varying interactions between the Sovereign CDS markets and the corresponding government bond markets of 33 worldwide countries are studied using both AR(1)FIEGARCH(1,d,1)-DCC and Bayesian VECM frameworks. The first approach allows us to define countries that are prone to contagion effects during crisis periods and to estimate the conditional means and volatility used to treat the heteroscedastic properties of our data. The transformed data are used to model a dynamic financial system, in the second approach, so we can quantify and ascertain the direction of the credit risk spillover.

Our findings reveal that some of the studied countries are prone to contagion phenomenon with a significant fluctuation of the dynamic conditional correlation in $21 \%(67 \%)$ of the credit markets during the financial (sovereign) crisis. Contagion effects are, thus, occurring in more countries during the second crisis period which implies that the European Debt crisis's intensity and severity are more important than in the Global Financial Crisis. Results at the aggregate geographical area level confirm that only Asian countries are hit by waves of contagion between credit markets during both crises while South America and Western Europe are only subjects to credit contagion respectively during the second crisis and the first crisis. 
The directions of the risk spillovers, as given by the second approach, are changing over time and across countries. The CDS market seems to incite crises transmission more that the bond market since 16 financial shock transmissions are detected from the CDS markets versus 9 to the CDS markets. Sub-period analysis affirms, once again, that crises increase the percentage of co-movements between credit markets and that the Sovereign Debt Crisis is more intense and affects more countries all over the world than the Financial Crisis.

The results of both econometric approaches show, globally, that worldwide countries exhibit different credit markets characteristics and present some reactions' divergences to crises. The findings highlight the importance of putting in place different economic and regulatory policies depending on country characteristics to control for credit risk propagation. A particular focus should be given by policymakers to credit markets' dynamic comovements during crisis periods. Markets' participants are also concerned by our findings so they can anticipate financial turmoil and appropriately balance risk against profitability in investment mix.

\section{References}

Amisano, G., Serati, M., 1999. Forecasting cointegrated series with bvar models. Journal of Forecasting 18, 463-476.

Ammer, J., Cai, F., 2011. Sovereign cds and bond pricing dynamics in emerging markets: Does the cheapest-to-deliver option matter? Journal of International Financial Markets, Institutions and Money 21, 369-387.

Audige, H., 2013. A new approach of contagion based on STCC-GARCH models: An empirical application to the Greek crisis. Technical Report. Working Paper Economix.

Baba, N., Inada, M., et al., 2007. Price discovery of credit spreads for Japanese mega-banks: Subordinated bond and CDS. Technical Report. Institute for Monetary and Economic Studies, Bank of Japan.

Baek, I.M., Jun, J., 2011. Testing contagion of the 1997-98 crisis in asian stock markets with structural breaks and incubation periods. Journal of Asian Economics 22, 356-368.

Bai, J., Collin-Dufresne, P., . The cds-bond basis .

Beber, A., Brandt, M.W., Kavajecz, K.A., 2009. Flight-to-quality or flight-to-liquidity? evidence from the euro-area bond market. Review of Financial Studies 22, 925-957.

Bhanot, K., Guo, L., 2011. Negative credit spreads: Liquidity and limits to arbitrage. The Journal of Fixed Income 21, 32-41.

Blanco, R., Brennan, S., Marsh, I.W., 2005. An empirical analysis of the dynamic relation between investment-grade bonds and credit default swaps. The Journal of Finance 60, $2255-2281$.

Bollerslev, T., Mikkelsen, H.O., 1996. Modeling and pricing long memory in stock market volatility. Journal of econometrics 73, 151-184. 
Bowe, M., Klimaviciene, A., Taylor, A.P., 2009. Information transmission and price discovery in emerging sovereign credit risk markets, in: Presentation at the Mid-West Finance Association Annual Conference, Chicago.

Buchholz, M., Tonzer, L., 2016. Sovereign credit risk co-movements in the eurozone: Simple interdependence or contagion? International Finance 19, 246-268.

Calice, G., Chen, J., Williams, J., 2013. Liquidity spillovers in sovereign bond and cds markets: An analysis of the eurozone sovereign debt crisis. Journal of Economic Behavior \& Organization 85, 122-143.

Calice, G., Ioannidis, C., 2012. An empirical analysis of the impact of the credit default swap index market on large complex financial institutions. International Review of Financial Analysis 25, 117-130.

Conrad, C., Karanasos, M., Zeng, N., 2011. Multivariate fractionally integrated aparch modeling of stock market volatility: A multi-country study. Journal of Empirical Finance $18,147-159$.

Cossin, D., Lu, H., et al., 2005. Are European Corporate Bond and Default Swap Markets Segmented? Technical Report. International Center for Financial Asset Management and Engineering.

Costantini, M., Fragetta, M., Melina, G., 2014. Determinants of sovereign bond yield spreads in the emu: An optimal currency area perspective. European Economic Review 70, 337349 .

Coudert, V., Gex, M., 2013. The interactions between the credit default swap and the bond markets in financial turmoil. Review of International Economics 21, 492-505.

Cuestas, J.C., 2017. House prices and capital inflows in spain during the boom: evidence from a cointegrated var and a structural bayesian var. Journal of Housing Economics 37, $22-28$.

Delatte, A.L., Gex, M., López-Villavicencio, A., 2012. Has the cds market influenced the borrowing cost of european countries during the sovereign crisis? Journal of International Money and Finance 31, 481-497.

Dimitriou, D., Kenourgios, D., Simos, T., 2013. Global financial crisis and emerging stock market contagion: A multivariate fiaparch-dcc approach. International Review of Financial Analysis 30, 46-56.

Dolvin, S.D., 2012. Negative Bond Yields. Technical Report. Bulter University. Working paper. 28.

Eichler, S., 2014. The political determinants of sovereign bond yield spreads. Journal of International Money and Finance 46, 82-103. 
Engle, R., 2002. Dynamic conditional correlation: A simple class of multivariate generalized autoregressive conditional heteroskedasticity models. Journal of Business \& Economic Statistics 20, 339-350.

Fantazzini, D., 2011. Fractionally integrated models for volatility: A review-empirical appendix: Some examples with r interfaced with the ox package g@rch. Available at SSRN 1752095 .

Félix, R.M., Nunes, L.C., et al., 2003. Forecasting euro area aggregates with Bayesian VAR and VECM models. Banco De Portugal, Economic Research Department.

Fontana, A., Scheicher, M., 2016. An analysis of euro area sovereign cds and their relation with government bonds. Journal of Banking \& Finance 62, 126-140.

Forbes, K.J., Chinn, M.D., 2004. A decomposition of global linkages in financial markets over time. Review of Economics and Statistics 86, 705-722.

Forte, S., Pena, J.I., 2009. Credit spreads: An empirical analysis on the informational content of stocks, bonds, and cds. Journal of Banking \& Finance 33, 2013-2025.

Gilchrist, S., Mojon, B., 2016. Credit risk in the euro area. The Economic Journal .

Granger, C.W., 1969. Investigating causal relations by econometric models and cross-spectral methods. Econometrica: Journal of the Econometric Society , 424-438.

Gyntelberg, J., Hördahl, P., Ters, K., Urban, J., 2013. Intraday dynamics of euro area sovereign CDS and bonds. Technical Report. Bank for International Settlements.

Hong, Y., 2001. A test for volatility spillover with application to exchange rates. Journal of Econometrics 103, 183-224.

Hull, J., Predescu, M., White, A., 2004. The relationship between credit default swap spreads, bond yields, and credit rating announcements. Journal of Banking \& Finance 28, 2789-2811.

Ismailescu, I., Phillips, B., 2015. Credit default swaps and the market for sovereign debt. Journal of Banking \& Finance 52, 43-61.

Johansen, S., et al., 1991. Estimation and hypothesis testing of cointegration vectors in gaussian vector autoregressive models. Econometrica: Journal of the Econometric Society 59, 1551-80.

Kalbaska, A., Gatkowski, M., 2012. Eurozone sovereign contagion: Evidence from the cds market (2005-2010). Journal of Economic Behavior and Organization 83, 657-673.

Kenourgios, D., Dimitriou, D., 2015. Contagion of the global financial crisis and the real economy: A regional analysis. Economic Modelling 44, 283-293.

Koop, G., Strachan, R.W., Dijk, H.K.v., Villani, M., 2005. Bayesian approaches to cointegratrion. Technical Report. Econometric Institute Research Papers. 
Lee, B.S., Paek, M., Ha, Y., Ko, K., 2015. The dynamics of market volatility, market return, and equity fund flow: International evidence. International Review of Economics \& Finance 35, 214-227.

Litterman, R.B., 1986. Forecasting with bayesian vector autoregressions - five years of experience. Journal of Business \& Economic Statistics 4, 25-38.

Longstaff, F.A., 2010. The subprime credit crisis and contagion in financial markets. Journal of financial economics 97, 436-450.

Longstaff, F.A., Mithal, S., Neis, E., 2005. Corporate yield spreads: Default risk or liquidity? new evidence from the credit default swap market. The Journal of Finance 60, 2213-2253.

Norden, L., Weber, M., 2009. The co-movement of credit default swap, bond and stock markets: An empirical analysis. European financial management 15, 529-562.

Sabkha, S., De Peretti, C., Hmaied, D., 2017. The credit default swap market contagion during recent crises: International evidence. Working paper.

Sims, C.A., 1980. Macroeconomics and reality. Econometrica: Journal of the Econometric Society , 1-48.

Srivastava, S., Lin, H., Premachandra, I.M., Roberts, H., 2016. Global risk spillover and the predictability of sovereign cds spread: International evidence. International Review of Economics \& Finance 41, 371-390.

Tamakoshi, G., Hamori, S., 2016. Time-varying co-movements and volatility spillovers among financial sector cds indexes in the uk. Research in International Business and Finance 36, 288-296.

Youssef, M., Belkacem, L., 2015. On the impact of oil price fluctuations on stock markets: A multivariate long-memory garch framework. World Academy of Science, Engineering and Technology, International Journal of Economics and Management Engineering, 2.

Yu, S., 2017. Sovereign and bank interdependencies - evidence from the cds market. Research in International Business and Finance 39, 68-84.

Zhu, H., 2006. An empirical comparison of credit spreads between the bond market and the credit default swap market. Journal of Financial Services Research 29, 211-235. 